University of Nebraska - Lincoln

DigitalCommons@University of Nebraska - Lincoln

USDA National Wildlife Research Center - Staff Publications
U.S. Department of Agriculture: Animal and Plant Health Inspection Service

2017

\title{
Can we save large carnivores without losing large carnivore science?
}

\author{
Benjamin L. Allen \\ University of Southern Queensland, benjamin.allen@usq.edu.au \\ Lee R. Allen \\ Queensland Department of Agriculture and Fisheries, lee.allen@daf.qld.gov.au \\ Henrik Andrén \\ Swedish University of Agricultural Sciences, Henrik.Andren@slu.se \\ Guy Ballard \\ University of New England, guy.ballard@dpi.nsw.gov.au \\ Luigi Boitani \\ University of Rome, luigi.boitani@uniroma1.it
}

See next page for additional authors

Follow this and additional works at: https://digitalcommons.unl.edu/icwdm_usdanwrc

Part of the Life Sciences Commons

Allen, Benjamin L.; Allen, Lee R.; Andrén, Henrik; Ballard, Guy; Boitani, Luigi; Engeman, Richard M.; Fleming, Peter J. S.; Ford, Adam T.; Haswell, Peter M.; Kowalczyk, Rafal; Linnell, John D. C.; Mech, L. David; and Parker, Daniel M., "Can we save large carnivores without losing large carnivore science?" (2017). USDA National Wildlife Research Center - Staff Publications. 1990.

https://digitalcommons.unl.edu/icwdm_usdanwrc/1990

This Article is brought to you for free and open access by the U.S. Department of Agriculture: Animal and Plant Health Inspection Service at DigitalCommons@University of Nebraska - Lincoln. It has been accepted for inclusion in USDA National Wildlife Research Center - Staff Publications by an authorized administrator of DigitalCommons@University of Nebraska - Lincoln. 


\section{Authors}

Benjamin L. Allen, Lee R. Allen, Henrik Andrén, Guy Ballard, Luigi Boitani, Richard M. Engeman, Peter J. S. Fleming, Adam T. Ford, Peter M. Haswell, Rafal Kowalczyk, John D. C. Linnell, L. David Mech, and Daniel M. Parker 


\section{Can we save large carnivores without losing large carnivore science?}

\section{Benjamin L. Allen ${ }^{\mathrm{a}, *}$, Lee R. Allen ${ }^{\mathrm{b}}$, Henrik Andrén ${ }^{\mathrm{c}}$, Guy Ballard ${ }^{\mathrm{d}}$, Luigi Boitani ${ }^{\mathrm{e}}$, Richard M. Engeman ${ }^{\mathrm{f}}$, Peter J.S. Fleming ${ }^{\mathrm{g}}$, Adam T. Ford ${ }^{\mathrm{h}}$, Peter M. Haswell ${ }^{\mathrm{i}}$, Rafał Kowalczyk ${ }^{\mathrm{j}}$, John D.C. Linnell ${ }^{\mathrm{k}}$,} L. David Mech ${ }^{1}$, Daniel M. Parker ${ }^{\mathrm{m}}$

a University of Southern Queensland, Institute for Agriculture and the Environment, Toowoomba, Queensland 4350, Australia

${ }^{\mathrm{b}}$ Robert Wicks Pest Animal Research Centre, Biosecurity Queensland, Queensland Department of Agriculture and Fisheries, Toowoomba, Queensland 4350, Australia

c Grimsö Wildlife Research Station, Department of Ecology, Swedish University of Agricultural Sciences (SLU), SE-73091 Riddarhyttan, Sweden

d Vertebrate Pest Research Unit, New South Wales Department of Primary Industries, The University of New England, Armidale, New South Wales 2351, Australia

e Department of Biology and Biotechnologies, University of Rome, Sapienza, 00185 Rome, Italy

${ }^{\mathrm{f}}$ National Wildlife Research Centre, US Department of Agriculture, Fort Collins, CO 80521-2154, United States

g Vertebrate Pest Research Unit, New South Wales Department of Primary Industries, Orange, New South Wales 2800, Australia

${ }^{\mathrm{h}}$ Department of Biology, University of British Columbia, Kelowna V1V1V7, Canada

${ }^{i}$ School of Biological Sciences, Bangor University, Bangor, Gwynedd LL57 2DG, United Kingdom

${ }^{\mathrm{j}}$ Mammal Research Institute, Polish Academy of Sciences, 17-230 Białowieża, Poland

${ }^{\mathrm{k}}$ Norwegian Institute for Nature Research, PO Box 5685, Sluppen, NO-7485 Trondheim, Norway

${ }^{1}$ Northern Prairie Wildlife Research Centre, US Geological Survey, 8711 -37 ${ }^{\text {th }}$ Street, SE, Jamestown, ND 58401-7317, USA

${ }^{\mathrm{m}}$ School of Biology and Environmental Sciences, University of Mpumalanga, Nelspruit 1200, South Africa

\section{A R T I C L E I N F O}

\section{Article history:}

Received 23 December 2016

Accepted 27 February 2017

Available online 1 March 2017

\section{Keywords:}

Apex predator

Behaviourally-mediated trophic cascades

Adaptive management

Experimental design

Mesopredator release hypothesis

Science denial

\begin{abstract}
A B S T R A C T
Large carnivores are depicted to shape entire ecosystems through top-down processes. Studies describing these processes are often used to support interventionist wildlife management practices, including carnivore reintroduction or lethal control programs. Unfortunately, there is an increasing tendency to ignore, disregard or devalue fundamental principles of the scientific method when communicating the reliability of current evidence for the ecological roles that large carnivores may play, eroding public confidence in large carnivore science and scientists. Here, we discuss six interrelated issues that currently undermine the reliability of the available literature on the ecological roles of large carnivores: (1) the overall paucity of available data, (2) reliability of carnivore population sampling techniques, (3) general disregard for alternative hypotheses to top-down forcing, (4) lack of applied science studies, (5) frequent use of logical fallacies, and (6) generalisation of results from relatively pristine systems to those substantially altered by humans. We first describe how widespread these issues are, and given this, show, for example, that evidence for the roles of wolves (Canis lupus) and dingoes (Canis lupus dingo) in initiating trophic cascades is not as strong as is often claimed. Managers and policy makers should exercise caution when relying on this literature to inform wildlife management decisions. We emphasise the value of manipulative experiments and discuss the role of scientific knowledge in the decision-making process. We hope that the issues we raise here prompt deeper consideration of actual evidence, leading towards an improvement in both the rigour and communication of large carnivore science.
\end{abstract}

(c) 2017 Elsevier Inc. All rights reserved.

\section{Contents}

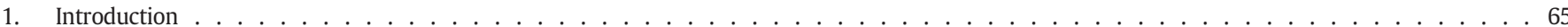

2. Issues that weaken the available literature supporting the $\mathrm{MRH}, \mathrm{TCH}$ and $\mathrm{BMTCH} \ldots \ldots \ldots$

2.1. There is not enough evidence of any kind, reliable or otherwise . . . . . . . . . . . . . . . . . . . . . . . 66

2.2. Sampling methods for carnivores are often unreliable . . . . . . . . . . . . . . . . . . . . . . . . . . . . . 67

2.3. Alternative hypotheses are seldom tested . . . . . . . . . . . . . . . . . . . . . . . . . . . . 67

\footnotetext{
* Corresponding author.

E-mail addresses: benjamin.allen@usq.edu.au (B.L. Allen), lee.allen@daf.qld.gov.au (L.R. Allen), Henrik.Andren@slu.se (H. Andrén), guy.ballard@dpi.nsw.gov.au (G. Ballard), luigi.boitani@uniroma1.it (L. Boitani), Richard.M.Engeman@aphis.usda.gov (R.M. Engeman), peter.fleming@dpi.nsw.gov.au (P.J.S. Fleming), adam.ford@ubc.ca (A.T. Ford), p.m.haswell@bangor.ac.uk (P.M. Haswell),rkowal@ibs.bialowieza.pl (R. Kowalczyk), John.Linnell@nina.no (J.D.C. Linnell),david_mech@usgs.gov (L. David Mech), Daniel.Parker@ump.ac.za (D.M. Parker).
} 


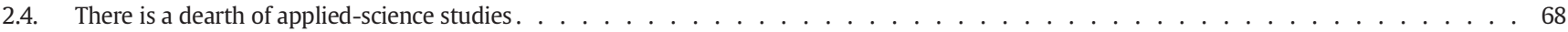

2.5. Logical fallacies underpin much of the literature. . . . . . . . . . . . . . . . . . . . . . . . . . . . . . . 69

2.6. Most of the 'best evidence' comes from ecosystems that do not represent the majority of the earth's surface or species . . . . . . . . . . . 69

3. Implications for large carnivore science and management . . . . . . . . . . . . . . . . . . . . . . . . . . 70

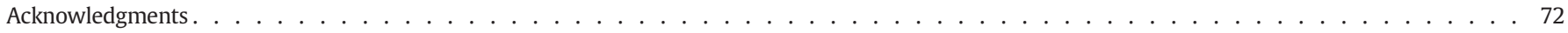

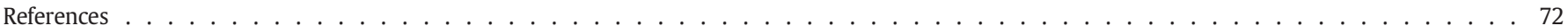

\section{Introduction}

Large carnivores are some of the most charismatic and ecologicallyinfluential organisms on Earth. Through their interactions with other animals, large carnivores may affect faunal and floral communities across multiple trophic levels (Darwin, 1859; Leopold, 1949; Hairston et al., 1960). This process is known as a trophic cascade (Paine, 1980), and is a concept now fully entrenched amongst ecologists, conservation biologists and many land and wildlife managers.

Seldom have such novel ecological concepts been so rapidly mainstreamed to the extent that they are identified as one of the 20 most influential topics in biodiversity conservation (Bradshaw et al., 2011). Yet the 'mesopredator release hypothesis' (MRH) and its cousins the 'large-carnivore control-induced trophic cascade hypothesis' (TCH) and the 'behaviourally-mediated trophic cascade hypothesis' (BMTCH) have done exactly that, so much so that these concepts are now routinely advanced as scientific and moral justification for what are essentially highly normative standpoints concerning desired conservation outcomes. Inherently value-laden, religious terms are now frequently used in academic discourses about the ecological roles of large carnivores - terms such as hero, doctrine, dogma, demonising, virtuous, saviour, scapegoat, sanctification, sinners, and saints (e.g. Jones, 2002; Soulé et al., 2005; Anahita and Mix, 2006; Allen et al., 2011a; Letnic et al., 2011; Mech, 2012; Chapron and Lopez-Bao, 2014; Middleton, 2014; Johnson and Wallach, 2016). Unfortunately, but perhaps motivated by the dire status of many carnivore populations, a growing number of studies rely on weak inference when valuing the roles of large carnivores in ecosystems (e.g. Allen et al., 2013b; Ford and Goheen, 2015). Such practices might stimulate short-term gains in carnivore conservation and motivate some segments of the public to care about it, but these communication practices risk undermining long-term confidence in large carnivore science and scientists (Fleming et al., 2012; Sarewitz, 2012; Middleton, 2014). The actual science of large carnivore science is now getting lost, being replaced by catch phrases, slogans, sound bites, YouTube clips, fake news and post-truth politics, or the simplification and popularisation of unsubstantiated or unreliable opinions, theories and hypotheses. This tension between scientific rigour and pursuit of quick conservation gain raises the critical question: can ecologists save large carnivores without losing large carnivore science?

As described in several studies (summarised, for example, in Crooks and Soulé, 1999; Hayward and Somers, 2009; Terborgh and Estes, 2010; Eisenberg, 2011; Estes et al., 2011; Ritchie et al., 2012; Ripple et al., 2014b; but for a clear definition see Ripple et al., 2016b), the core theoretical processes associated with the MRH, TCH and BMTCH are:

1. Mesopredators and herbivores induce declines in smaller fauna and flora,

2. Large carnivores induce declines in mesopredators and herbivores,

3. Lethal control, harvest or hunting of large carnivores by humans induces declines in large carnivores, increases in mesopredators and herbivores, and ultimately causes undesirable outcomes for biodiversity and ecosystems,

4. Cessation of large carnivore control, harvest or hunting and/or active large carnivore encouragement, including reintroduction, induces declines in mesopredators and herbivores, which ultimately causes desirable outcomes for biodiversity and ecosystems, and
5. Documentation of the MRH, TCH and BMTCH in some studies has been common enough that these processes should be considered universal across ecosystem types and independent of carnivore size or phylogeny.

The way these theories have been mainstreamed are perhaps best encapsulated in the short online video titled How wolves change rivers (Sustainable Human, 2014), which has been viewed over 34 million times since early 2014, but which does not consider the contrary (and often superior) evidence for the processes it claims. Proponents of the $\mathrm{MRH}, \mathrm{TCH}$, and BMTCH argue that these hypotheses should be accepted by scientists and society as ecological laws by default (not as mere theories or hypotheses) and that the burden of proof for demonstrating their reality should be placed on those who do not believe them (Estes et al., 2011). These theories also provide the scientific justification for many admirable and worthwhile efforts to restore large carnivore populations to densities and distributions reminiscent of former times (Ripple et al., 2014b; Ripple et al., 2016a), although historical ecological benchmarks have not been determined for most systems (e.g. Hayward, 2012). Nevertheless, the worldwide influence of the MRH, TCH and BMTCH have been enormous (Bradshaw et al., 2011). In spite of the perceived universality of top-down control of ecosystems however, there is a large and growing number of large carnivore studies indicating that

\section{Table 1}

Some recent lines of debate discussing large carnivores' roles in trophic cascades in Australia, demonstrating that evidence for the ecological roles of dingoes is equivocal, primarily due to the six issues described in the present article.

\begin{tabular}{|c|c|c|}
\hline Debated topic & $\begin{array}{l}\text { Chronological } \\
\text { order }\end{array}$ & Reference \\
\hline \multirow{2}{*}{$\begin{array}{l}\text { Trophic cascades following dingo } \\
\text { control }\end{array}$} & 1 & Wallach and O'Neill (2009) \\
\hline & 2 & Allen $(2010)$ \\
\hline \multirow[t]{4}{*}{ Ecological niche of dingoes } & 1 & Fleming et al. (2012) \\
\hline & 2 & Johnson and Ritchie (2013) \\
\hline & 3 & Fleming et al. (2013) \\
\hline & 4 & Claridge (2013) \\
\hline \multirow[t]{2}{*}{ Dingo predation risk to fauna } & 1 & Dickman et al. (2009) \\
\hline & 2 & Allen and Fleming (2012) \\
\hline \multirow{5}{*}{$\begin{array}{l}\text { Methodological problems with } \\
\text { dingo studies }\end{array}$} & 1 & Allen et al. (2011a) \\
\hline & 2 & Letnic et al. (2011) \\
\hline & 3 & Allen et al. (2011b) \\
\hline & 4 & Glen (2012) \\
\hline & 5 & Allen et al. (2013b) \\
\hline \multirow{2}{*}{$\begin{array}{l}\text { Cause of historical declines of } \\
\text { marsupials }\end{array}$} & 1 & Johnson et al. (2007) \\
\hline & 2 & Allen (2011) \\
\hline \multirow{2}{*}{$\begin{array}{l}\text { Importance of dingo social } \\
\text { structure }\end{array}$} & 1 & Wallach et al. (2009) \\
\hline & 2 & Allen (2012b) \\
\hline \multirow{3}{*}{$\begin{array}{l}\text { Trophic cascades following dingo } \\
\text { control }\end{array}$} & 1 & Colman et al. (2014) \\
\hline & 2 & Allen (2015b) \\
\hline & 3 & Colman et al. (2015) \\
\hline \multirow[t]{4}{*}{ Effects of dingoes on sheep } & 1 & East and Foreman (2011) \\
\hline & 2 & Allen and West (2013) \\
\hline & 3 & Forsyth et al. (2014) \\
\hline & 4 & Allen and West (2015) \\
\hline \multirow{7}{*}{$\begin{array}{l}\text { Trophic cascades following dingo } \\
\text { control }\end{array}$} & 1 & Allen et al. (2013a) \\
\hline & 2 & Johnson et al. (2014) \\
\hline & 3 & Allen et al. (2014a) \\
\hline & 4 & Allen et al. (2014b) \\
\hline & 5 & Hayward and Marlow (2014) \\
\hline & 6 & Nimmo et al. (2015) \\
\hline & 7 & Hayward et al. (2015) \\
\hline
\end{tabular}


Table 2

Some recent lines of debate discussing large carnivores' roles in trophic cascades in North America, demonstrating that evidence for the ecological roles of wolves is equivocal, primarily due to the six issues described in the present article.

\begin{tabular}{|c|c|c|}
\hline Debated topic & $\begin{array}{l}\text { Chronological } \\
\text { order }\end{array}$ & Reference \\
\hline \multirow{12}{*}{$\begin{array}{l}\text { Wolf-induced } \\
\text { behaviourally-mediated trophic } \\
\text { cascades in Yellowstone }\end{array}$} & 1 & Ripple and Beschta (2004) \\
\hline & 2 & Kauffman et al. (2007) \\
\hline & 3 & Ripple and Beschta (2007) \\
\hline & 4 & Kauffman et al. (2010) \\
\hline & 5 & Kimble et al. (2011) \\
\hline & 6 & Winnie (2012) \\
\hline & 7 & Beschta and Ripple (2013) \\
\hline & 8 & Kauffman et al. (2013) \\
\hline & 9 & Middleton et al. (2013a) \\
\hline & 10 & Beschta et al. (2014) \\
\hline & 11 & Winnie (2014) \\
\hline & 12 & Painter et al. (2015) \\
\hline \multirow{13}{*}{$\begin{array}{l}\text { Willow recovery in Yellowstone } \\
\text { following wolf reintroduction }\end{array}$} & 1 & Ripple and Beschta (2003) \\
\hline & 2 & Despain (2005) \\
\hline & 3 & Ripple and Beschta (2006) \\
\hline & 4 & Wolf et al. (2007) \\
\hline & 5 & Beyer et al. (2007) \\
\hline & 6 & Bilyeu et al. (2008) \\
\hline & 7 & Creel and Christianson (2009) \\
\hline & 8 & Tercek et al. (2010) \\
\hline & 9 & Johnston et al. (2011) \\
\hline & 10 & Middleton et al. (2013a) \\
\hline & 11 & Marshall et al. (2013) \\
\hline & 12 & Marshall et al. (2014) \\
\hline & 13 & Smith et al. (2016) \\
\hline \multirow{2}{*}{$\begin{array}{l}\text { Trophic cascades and Mexican } \\
\text { wolves }\end{array}$} & 1 & Beschta and Ripple (2010) \\
\hline & 2 & Mech (2012) \\
\hline \multirow[t]{4}{*}{ Wolf effects on lynx } & 1 & Ripple et al. (2011) \\
\hline & 2 & Hodges (2012) \\
\hline & 3 & Squires et al. (2012) \\
\hline & 4 & Wirsing et al. (2012) \\
\hline \multirow[t]{3}{*}{ Wolf effects on bears } & 1 & Ripple et al. (2014a) \\
\hline & 2 & Barber-Meyer (2015) \\
\hline & 3 & Ripple et al. (2015) \\
\hline \multirow{5}{*}{$\begin{array}{l}\text { Ethics and effects of predator } \\
\text { control for moose conservation } \\
\text { in Alaska }\end{array}$} & 1 & WMRC (1996) \\
\hline & 2 & Orians et al. (1997) \\
\hline & 3 & Van Ballenberghe (2006) \\
\hline & 4 & Boertje et al. (2010) \\
\hline & 5 & Kennedy and Fiorino (2011) \\
\hline
\end{tabular}

such effects are highly context specific and that many of the most rigorous studies fail to document evidence of trophic cascades (Tables 1-3).

In this brief overview, we summarise six key issues weakening the strength of the available literature and undermining scientific advancement on understanding large carnivores' ecological roles. We focus our discussion on grey wolves (Canis lupus) and Australian dingoes (Canis lupus dingo), which have been claimed to be the only two terrestrial carnivores for which both the MRH and TCH have been demonstrated (Fig. S2 in Ripple et al., 2014b). Our aim is not to denigrate these or other large carnivores, decrease interest in them, diminish the motivation to conserve them, or hinder the pursuit of scientific knowledge in this field. On the contrary, our aim is to outline the primary issues weakening the reliability of research on MRH, TCH and BMTCH, to show why wildlife managers and policy makers should exercise caution when making decisions based on the currently available literature describing these processes. We agree with many authors that top-down forcing can occur and that large carnivores can have important ecological roles. However, there are enormous gaps in our understanding of when and where such effects will occur in most systems. Articulating the truth about the reliability (or lack thereof) of large carnivore science is, in and of itself, a strong conservation message: it is far better to err on the side of caution and preserve large carnivores in the first place than to falsely believe ecosystems can be quickly and easily fixed, restored or rewilded by simply bringing some carnivores back (Glen et al., 2007; Marshall et al., 2016). We further offer suggestions for
Table 3

Some recent lines of debate discussing large carnivores' roles in trophic cascades in Europe, demonstrating that evidence for the ecological roles of large carnivores is equivocal, primarily due to the six issues described in the present article.

\begin{tabular}{lll}
\hline & $\begin{array}{l}\text { Chronological } \\
\text { Debated topic }\end{array}$ & Reference \\
\hline Human influence on & 1 & Melis et al. (2009) \\
trophic cascades in & 2 & Kuijper (2011) \\
Europe & 3 & Dorresteijn et al. (2015) \\
& 4 & Kuijper et al. (2016) \\
& 5 & Ritchie et al. (2016) \\
Large carnivore & 1 & Palomares et al. (1995) \\
impacts on & 2 & Palomares et al. (1998) \\
mesocarnivores & 3 & Sunde et al. (1999) \\
& 4 & Linnell and Strand (2002) \\
& 5 & Helldin et al. (2006) \\
& 6 & Elmhagen and Rushton (2007) \\
& 7 & Kowalczyk et al. (2009) \\
& 8 & Pasanen-Mortensen et al. (2013) \\
& 9 & Wikenros et al. (2014) \\
& 10 & Pasanen-Mortensen and Elmhagen (2015) \\
\hline
\end{tabular}

overcoming these issues with the hope that future large carnivore studies will avoid them and better contribute to the evidence-base needed for the management and conservation of large carnivores and sympatric species.

\section{Issues that weaken the available literature supporting the MRH, TCH and BMTCH}

\subsection{There is not enough evidence of any kind, reliable or otherwise}

A general understanding of large carnivores' roles is only beginning to emerge, and much more work is needed before we can confidently claim what those roles are or the ecological contexts that shape these roles. Large carnivores unquestionably have ecological effects or impacts of some description. In principle, every individual animal eaten or scared by a carnivore represents an impact - the prey animal flees or dies, the prey's population growth or foraging is slowed, scavengers scavenge, decomposers decompose, nutrients enter the soil, life for the prey's competitor is now a little easier, the vegetation that would have been consumed by the prey survives a little longer, and the carnivore lives to kill another day. Whether the death of that prey animal is a good or bad thing (or not) depends on the perspective of which animal is favoured over another (Allen et al., 2011b; Mech, 2012) - there are winners and losers to every interaction (Flagel et al., 2017). These interactions all have a value, contributing to the building blocks of wider ecological and demographic processes, and evolutionary selection pressures (Darwin, 1859; Hairston et al., 1960; Kershaw, 1969; Barbosa and Castellanos, 2005; Krebs, 2008; Molles, 2012). But do these individual-level impacts of a relatively small magnitude combine and accumulate to produce detectable cascading impacts of a large magnitude on populations and whole ecosystems? Are these carnivore effects stronger or more important at shaping systems than bottom-up processes? Can a few individual carnivores regulate entire food webs? Do carnivore effects always produce net benefits to biodiversity? Are positive carnivore effects universal across ecosystems and apparent across all trophic levels?

In spite of claims for the universality of trophic cascades and a concomitant shift in the burden of proof to disprove top-down forcing and prove bottom-up forcing (Terborgh and Estes, 2010; Estes et al., 2011), Haswell et al. (2017) show that at best, detectably large cascading effects of top-predators (from a wide range of taxonomic groups) are the exception and not the rule. Indeed, several studies using strongly-inferential methods demonstrate that such top-down effects do not always occur, or if they do, they are far weaker than bottom-up processes (e.g.Gasaway et al., 1983; Boertje et al., 1996; Hayes et al., 2003; Vucetich and Peterson, 2004; Vucetich et al., 2005; Brodie and 
Giordano, 2013; Marshall et al., 2013; Allen et al., 2014b; Ford et al., 2015a; Sivy, 2015; see also Schmitz et al., 2000; Bowyer et al., 2005; Sergio et al., 2008; McCoy et al., 2012; White, 2013; McPeek, 2014; Kuijper et al., 2017). Ford and Goheen (2015) showed that of five strongly-inferential experiments investigating large carnivores' roles, only two found evidence supporting the TCH. Morgan et al. (2017) highlight the supremacy of bottom-up processes and articulate the folly of attempting to shoe-horn or apply outcomes from one ecological context into another. Recent global reviews of the topic have also reported that 'little is known' about 24 of the 31 species of the world's largest carnivores, as ecologists are only just beginning to discover their ecological functions (Ripple et al., 2014b); or put another way, the MRH, TCH and BMTCH have not yet been shown for at least $77 \%$ of large carnivores. Hence, we do not yet know what the ecological functions of large carnivores are, and what we do know is from a minority of species in an even smaller minority of biomes. While these hypotheses might eventually be applied to, and supported in, a wide number of food webs, evidence supporting these hypotheses are currently quite restricted.

Ripple et al. (2014b) claim that both the MRH and the TCH have been demonstrated only for two related species, grey wolves and Australian dingoes, but the evidence-base for these two species is very limited. In the case of dingoes, the total number of field studies on their ecological roles is just a few dozen. Of these studies, all but four are observational or correlative studies conducted in small areas (i.e. a few hundred $\mathrm{km}^{2}$ ) and over only a few days (Allen et al., 2013b; Allen et al., 2015). Drawing on this limited pool of empirical data, the 22 literature reviews of dingoes' ecological roles produced over the last 10 years have unavoidably borrowed heavily from each other in what might be called citation inbreeding (Allen et al., 2014c). Thus, there is not a growing body of reliable evidence for dingoes' ecological roles at all, but merely a growing body of largely recycled literature (Table 1; see also Allen et al., 2011b). Evidence for the ecological roles of wolves is much stronger than dingoes, but is still frequently challenged and often found unreliable for similar reasons (Tables 2 and 3; see also Winnie and Creel, 2017). The combination of mixed-outcomes when testing the MRH, TCH and BMTCH and the absence of studies on most species of large carnivore warrants far greater circumspection than is often afforded in syntheses of carnivore ecology and conservation.

\subsection{Sampling methods for carnivores are often unreliable}

Studies measuring the effects of large carnivores' roles typically correlate some change or difference within an ecosystem to some change or difference in carnivore abundance (Ford and Goheen, 2015). But such approaches are frequently challenged because of their lack of rigour (Tables 1-3). These challenges usually fall into three main categories of complaint: experimental design constraints (e.g. manipulative experiments vs correlations or observations; alternative hypotheses), predator sampling strategies (e.g. tracking plots, camera traps, direct observations, movement data etc.), and data analysis approaches (e.g. indices, occupancy modelling, statistical assumption violations, exclusion/inclusion of outliers or contradictory data etc.). Counting or indexing carnivore populations can be difficult and is often associated with large confidence intervals, but analytical methods do exist to detect broad differences (e.g. Kershaw, 1969; Caughley, 1980; Underwood, 1997; Zar, 1999; Quinn and Keough, 2002; Krebs, 2008; Engeman et al., 2017). Unfortunately, many studies use carnivore sampling methods that are incapable of yielding reliable data on carnivore abundance, let alone actual rates of predation or perception of risk by prey animals. The absence of these data undermines evidence for the proposed link between variation in carnivore abundance and other reported changes and/or differences in the ecosystem.

Studies concluding that dingoes trigger trophic cascades are derived from non-validated and often confounded comparisons of population indices between habitats, season, and/or species (Allen et al., 2011a; Allen, 2012b). Ways to validate some common sampling methods have been developed (Allen and Engeman, 2014). When their methods are scrutinised, the results of the most oft-cited works are unreliable (Allen et al., 2014c). Even the results of the best available manipulative experiments are sometimes contested on grounds that the predator sampling methods are unreliable (e.g. Table 1 ).

There is unlikely to ever be any one perfect predator sampling method that suits all applications, so the use of different sampling techniques and analytical methods across studies is not particularly concerning. It does not matter if carnivores are sampled using sand plots, camera traps, snow tracking, GPS collaring, direct observations, or remote sensing (for example) provided the data are subsequently handled and analysed appropriately. We argue instead, that it is important to ensure that whatever the implicit assumptions of the methods are, that they are justifiable for the context under which the study was conducted (Engeman, 2005; Allen and Engeman, 2014). The weaknesses and limitations of these survey methods need to be openly acknowledged and discussed - not only in the peer-reviewed manuscript, but also in the subsequent public discourse. This is where many previous studies have erred (Table 1 ), and where improvements must be made if science is to acquire less ambiguous evidence to support the MRH, TCH or BMTCH (Hayward et al., 2015).

\subsection{Alternative hypotheses are seldom tested}

Carnivores are just one of many potential causal agents operating in ecosystems (Vucetich et al., 2005; Middleton, 2014; Peterson et al., 2014; Ford and Goheen, 2015). Yet for many studies claiming support for the MRH, TCH and BMTCH, the study framework is designed to create evidence for these hypotheses rather than being designed so that evidence for plausible alternative hypotheses is both tested and compared at the same time (Winnie, 2014). Studies investigating these hypotheses commonly focus on competition, predation/removal or risk of predation (Tables 1-3). But there are many more interaction types besides these within food webs, which interaction types can also be strong and often do not conform to simple expectations (Muhly et al., 2013; Saggiomo et al., 2017). Invertebrate (Meadows et al., 2017) and theoretical (e.g. Finke and Denno, 2004; Holt and Huxel, 2007; McCoy et al., 2012; McPeek, 2014; Kendall, 2015) studies highlight many different outcomes of predator removal or addition, most of which have received little attention in the wider large carnivore literature (Fleming et al., 2012; Mech, 2012; Ford and Goheen, 2015; Haswell et al., 2017). The consequence of not investigating plausible alternative explanations is that management actions may completely overlook key processes contributing to declines of fauna (e.g. Allen, 2011; Middleton et al., 2013b; Cooke and Soriguer, 2017), and they cannot discover these processes because the study framework simply corroborates a narrow set of a priori hypotheses without looking for others.

A clear example of the systemic failure to evaluate alternative hypotheses and ignore contrary data comes from a series of studies conducted in the Greater Yellowstone Ecosystem, USA (Winnie, 2014). Environmental changes following the restoration of wolves to Yellowstone National Park are often given as a clear example of the beneficial effects of restoring large carnivores to ecosystems (Table 2), but there are alternative hypotheses to explain many of the observed changes (Vucetich et al., 2005; Marshall et al., 2013; Middleton et al., 2013b). There is strong evidence that wolves alone are not responsible for all the changes attributed to them (Mech, 2012; Winnie and Creel, 2017). Many other important changes to the Yellowstone system occurred around the same time as wolf restoration, and 'when we tell the wolf story, we get the Yellowstone story wrong' (Middleton, 2014). Using data from 1961 to 2004, Vucetich et al. (2005) investigated the TCH and showed that changes in climate and harvest rate are justified explanations for most of the observed decline in Yellowstone elk, rather than heightened predation by wolves. Indeed, wolf predation was determined to be compensatory to existing rates of mortality (e.g. from starvation or mortality from other predators). In addition, early studies on 
the BMTCH reported that wolves scared herbivores away from riparian areas, which reduced herbivory on trees and ultimately caused increased tree growth (Ripple and Beschta, 2004; Beschta and Ripple, 2007). Not only did these earlier studies incorrectly identify areas of high predation risk (Creel et al., 2005; Kauffman et al., 2007; Kauffman et al., 2010; Winnie, 2012), but they also failed to consider more parsimonious explanations for increased tree growth in riparian areas, such as the height of the local water table (Bilyeu et al., 2008; Kauffman et al., 2013). MacNulty et al. (2016; pg. 27) summarise the present situation when they state that 'scientific consensus about the role of wolves in driving [trophic cascades] has yet to emerge, despite 20 years of research by numerous federal, state and academic investigators', and that the 'overarching reason for the impasse' is the experimental design constraints on the Yellowstone wolf reintroduction program. In other words, the lack of rigour and strong inference in testing the $\mathrm{MRH}, \mathrm{TCH}$ and BMTCH has generated the controversy over the role of wolves in restoring this Yellowstone landscape.

In Australia, snap-shot studies comparing fauna abundances in adjacent areas separated by predator-proof fences are commonly used to highlight the greater amount of biodiversity present on the side of the fence with a greater number of dingoes (e.g. Letnic et al., 2009; Fillios et al., 2010; Letnic and Koch, 2010; Brawata and Neeman, 2011; Gordon et al., 2017a). However, the relative abundance of dingoes is not the only important difference between the two sides of these fences (e.g. Newsome et al., 2001; Fitzsimmons, 2007; Allen, 2011). A range of important geological and biophysical differences are also present, not the least of which are the markedly different herbivore types, densities, and land-use histories, which are also well-known to structure fauna communities through grazing-induced habitat changes independent of dingoes or other predators (Tiver and Andrew, 1997; Williams and Price, 2010; Parsons et al., 2012; Howland et al., 2014; Koerner and Collins, 2014). The cross-fence differences are obvious, but their causes are not. In spite of the appearance of a grandiose 'natural experiment', the cross-fence comparisons are often poorly replicated and confounded. Nonetheless, studies adopting this design have formed the bulwark of claims about dingoes' ecological roles (Letnic et al., 2012; Allen et al., 2013b; Glen and Woodman, 2013). Until more rigorous experimental designs are implemented, further studies predicated on such correlative, cross-fence differences do little to increase evidence for the ecological role of dingoes.

The management consequences of failing to address alternative hypotheses are exemplified by the relatively simple carnivore system in Australia. Johnson et al. (2007) argued that human control of dingoes in the last 200 years caused the continental collapse of marsupial communities across Australia, but the role of the continental invasion of European rabbits (Oryctolagus cuniculus; Cooke and Soriguer, 2017) and the historical grazing of introduced sheep (Ovis aries) coupled with drought (Allen, 2011) were not properly assessed as potential causal factors for marsupial decline. Johnson and colleagues continue to assert that if only dingo persecution stopped, dingoes would suppress introduced rabbits, red foxes (Vulpes vulpes) and feral cats (Felis catus), and facilitate the recovery of reintroduced marsupials and other small mammals across the continent (e.g. Johnson, 2006; Wallach et al., 2009; Ritchie et al., 2012; Letnic et al., 2013). But such reintroductions continue to fail largely because predators - including dingoes - keep quickly decimating reintroduced mammals (Christensen and Burrows, 1995; Moseby et al., 2011; Bannister, 2014; Armstrong et al., 2015; Bannister et al., 2016). All the dingoes occupying Australia did not prevent the historical establishment and expansion of rabbits, foxes or cats across the continent in the first place, nor did the presence of dingoes prevent the collapse of marsupial communities following the advent of these pests. Extant dingo populations, never managed by modern humans across roughly one-third of the Australian continent (Allen et al., 2015), have not facilitated extirpation of these pests or their impacts, nor facilitated the recovery of marsupials in these areas. Indeed, dingoes reach their highest densities in places with abundant rabbits (Bird,
1994; Allen, 2012a), suggesting that invasive species are supporting carnivores rather than large carnivores suppressing invasive species. Dingoes may even provide net benefits to invasive rabbits through mesopredator suppression, just as dingoes putatively benefit rabbitsized native mammals (Cooke and Soriguer, 2017; Gordon et al., 2017a). In concert with habitat changes (be these caused by livestock, fire or rabbits), dingo predation has been identified as a key driver of native mammal decline independent of foxes or cats (e.g. Kerle et al., 1992; Corbett, 2001; Lundie-Jenkins and Lowry, 2005; Barnes et al., 2008; Allen, 2011; Allen and Fleming, 2012; Allen and Leung, 2012). Yet dingoes are typically considered part of the solution to Australia's fauna extinction crisis, when they are also part of the problem. Continuing to ignore this and other alternative hypotheses wastes precious time in our collective efforts to conserve native fauna under real threat of extinction.

In complex carnivore communities (where a wide variety of individual large carnivores utilise a range of hunting strategies, resulting in increased heterogeneity in predator-prey interactions), even manipulative experiments still struggle to tease apart the relative influence of top-down and bottom-up processes (e.g. Gasaway et al., 1983; Boertje et al., 1996; Maron and Pearson, 2011; Sinclair et al., 2013; Ford et al., 2015b; Riginos, 2015). In fact, Riginos (2015) goes as far as to suggest that behaviourally-mediated trophic cascades are either weak or nonexistent in African savanna systems because of the large sizes of many of the herbivores (elephants, Loxodonta africana, in particular) and the over-riding effect of climate. Predator diversity is known to dampen trophic cascade effects in model systems (Finke and Denno, 2004), and top-down forcing is also known to attenuate down through trophic levels more rapidly than previously thought (Schmitz et al., 2000; Brodie et al., 2014).

One characteristic of overemphasising the current robustness of large carnivore science is ignoring, suppressing or omitting reference to alternative hypotheses and contrary data (Claridge, 2013; Winnie, 2014). This is easy for authors to do given the vast pool of citations to choose from (e.g. Tables 1-3) and the limited number of references a journal will typically accept. When accused of selective referencing, the plea of 'not enough room' (e.g. see Marris, 2014 for examples) does not promote objectivity and transparency. Rather, it disregards the legitimate scientific criticisms available and only widens the creeping cracks of bias described by Sarewitz (2012), who argued that research is riddled with systematic errors (see also Ioannidis, 2005, 2014) and that the ensuing debate then erodes public confidence in science itself (see also Fleming et al., 2012; Middleton, 2014). Although large-scale and observational 'natural experiments' have great value when their results are 'consistent with' or 'inconsistent with' a given hypothesis, plausible alternative explanations nonetheless require thorough exploration and ranking before reported results from 'natural experiments' become the basis for changes in practice or policy (Barley and Meeuwig, 2017). Investigating alternative hypotheses should be a greater priority in future research on large carnivore ecology.

\subsection{There is a dearth of applied-science studies}

Some research questions are largely academic (e.g. do species A and $B$ have overlapping diets?), whereas applied studies have direct and immediate relevance to land and fauna managers (e.g. do interventions $\mathrm{X}$ and $Y$ produce the same outcome for species $A$ and $B$ ?). The importance of understanding the ecological roles of large carnivores has implications for the conservation and management of threatened carnivores and other fauna, such as livestock, game, or threatened wildlife prey species (e.g. Boertje et al., 2010). Managers need information that considers both the pros and cons of various management interventions, and this is best achieved through manipulative experiments or adaptive-management studies that investigate applied-science issues (Glen et al., 2007; Hone, 2007; Hone et al., 2015). Questions about the 
conservation utility of large carnivores as tools to restore biodiversity across the landscape are answered much faster when truly applied questions are investigated.

Evidence for the effects of carnivore removal is also not the same thing as evidence for the effects of their recovery (e.g. ansiotropic vs isotropic effects; sensu Ford and Goheen, 2015). Simply re-establishing or bolstering large carnivores may not fix the many environmental problems that occurred as a result of (and/or in addition to) carnivore extirpation (Marshall et al., 2013; Marshall et al., 2014; Wikenros et al., 2015). In some cases, food web structure and ecological context may have changed irreversibly (for whatever reason), some niches may no longer exist, and a carnivore's function in the new ecosystem might now be different from their previous function. Changes in the physical environment caused by the removal of large carnivores may make the system resistant to complete restoration after large carnivores are restored. This 'change resistant' hypothesis was tested against the existing $\mathrm{TCH}$ in a replicated, randomized, manipulative experiment conducted over a decade. The hypothesis that wolf restoration had caused ecosystem reorganization was rejected (Marshall et al., 2014), yet subsequent literature ignored it and instead repeated the story (i.e. Sustainable Human, 2014) that the ecosystems of Yellowstone have been dramatically restored by wolves following their reintroduction. Restoring carnivore populations "to areas greatly modified by human disturbance may not restore systems to their former state" (Glen et al., 2007; pg. 498) and these new carnivore functions may not be viewed as desirable or produce net benefits to novel and still-changing ecosystems (Fleming et al., 2012; Flagel et al., 2017).

Large carnivore studies often report a negative relationship between larger carnivores and smaller or mesocarnivores, and are then quick to recommend wholesale changes to the way large carnivores are managed without first measuring any actual effect of carnivore management (e.g. hunting, removal, restoration) on large or small carnivores, herbivores or prey (for examples, see Letnic et al., 2009; Wallach et al., 2010; Colman et al., 2014; Gordon et al., 2017a; Gordon et al., 2017b). Equally, perceived negative impacts of carnivores on livestock have historically been addressed by wholesale lethal control without any recognition of the positive impacts that carnivores may have on the herbivores that compete with livestock or the consequences of lethal control on livestock losses (e.g. Wicks and Allen, 2012; Allen, 2014; Allen, 2015a; Prowse et al., 2015; Allen, 2017). Treves et al. (2016) and others (e.g. Reddiex and Forsyth, 2006; Doherty and Ritchie, 2017) rightly point out that many studies promoting predator control are badly designed, and we agree, but the same failing exists in many studies condemning predator control and promoting predator conservation. Unreliable science and poor science communication practices are a feature of literature expressing both positive and negative views towards carnivores (Boertje et al., 2010).

To make ecological data useful for improving carnivore management and conservation, researchers must provide managers with data they can apply. For example, when claiming that large carnivore control (i.e. trapping, hunting, or poisoning) must be banned in order to generate cascading, positive effects on biodiversity (e.g. Carwardine et al., 2012), information on the actual effects of carnivore hunting or poisoning on biodiversity are needed, not just information on how one carnivore species might interact with another (for examples, see Fleming et al., 2012; Allen et al., 2015). Conversely, when claiming that large carnivore control must be implemented to reduce livestock predation, information on actual carnivore impacts and impact reduction is required to ethically justify carnivore control (Braysher, 1993; Allen et al., 2014b; Allen, 2017). The paucity of applied ecological data in the wider large carnivore literature means that much of the presently available information on the MRH, TCH and BMTCH is not as useful to managers as it could be. This paucity also means that, in most cases, we do not yet have a solid understanding of the actual cascading effects, if any, of carnivore reintroduction, population control or manipulation (Ripple et al., 2014b; Newsome et al., 2015). This issue contributes to a significant knowledge-mobilization and implementation gap for large carnivore science.

\subsection{Logical fallacies underpin much of the literature}

Most research about the ecological roles of large carnivores is also grounded in two logical fallacies, post hoc ergo propter hoc and cum hoc ergo propter hoc. Post hoc ergo propter hoc is the notion that if $\mathrm{X}$ occurred before $\mathrm{Y}$, then $\mathrm{X}$ caused $\mathrm{Y}$. When $\mathrm{X}$ is undesirable, this pattern is often extended in reverse as: avoiding $\mathrm{X}$ will prevent $\mathrm{Y}$. Cum hoc ergo propter hoc is the notion that if $\mathrm{X}$ changed similarly to $\mathrm{Y}$, then $\mathrm{X}$ and $\mathrm{Y}$ are linked. The fallacies lie in coming to a conclusion based on the order or pattern of events, rather than accounting for other factors that might rule out a proposed connection.

Examples of post hoc ergo propter hoc in the large carnivore literature are rife and include, for example, conclusions to the effect that 'the ecological changes observed in Yellowstone National Park occurred after wolves were reintroduced, so wolves must have caused these ecological changes' (epitomised in Sustainable Human, 2014; see Table 2). Or alternatively, 'the last population of highly endangered mammals went extinct after predator control, so predator control must have caused the extinction through trophic cascade effects' (discussed in Fleming et al., 2013). There are also many examples of cum hoc ergo propter $h o c$, including almost all the relevant literature on dingoes' ecological roles (see Allen et al., 2013b; see Table 1). That wolves may not have been the cause of all the observed ecological changes in Yellowstone since the mid-1990s is argued by Kauffman et al. (2010), Mech (2012) and others (e.g.Creel and Christianson, 2009; Winnie, 2012; Marshall et al., 2013; Marshall et al., 2014; Middleton, 2014; Peterson et al., 2014; see Table 2). The long term study of wolf-moose (Alces americanus)-habitat-climate relationships on Isle Royale illustrate the difficulties of attributing cause and effect even in very simple ecosystems (Vucetich and Peterson, 2004). This case study stands out because researchers have explored multiple factors at the same time, have been excessively cautious in the language they use to attribute causality, and have constantly updated their views concerning the functioning of the ecosystem as new data becomes available. Shifting the research focus from 'trophic cascades' to 'food webs' in this way can help overcome the subtle yet troublesome overreliance on logical fallacies in studies of carnivores' ecological roles (Eisenberg et al., 2013).

2.6. Most of the 'best evidence' comes from ecosystems that do not represent the majority of the earth's surface or species

Although there are still some large tracts of relatively intact land in some places, the reality is that the majority of the earth's surface has been substantially altered by humans, and continues to be altered, in a modern epoch now labelled as the Anthropocene (Zalasiewicz et al., 2008; Kueffer and Kaiser-Bunbury, 2013). Modern, human-dominated ecosystems typically comprise mixed land-uses including urbanisation, forestry, mining, hunting, recreation, agriculture (crops and/or livestock production) or other areas fragmented by roads, railways and fences, and containing exotic plant and animal species and artificial water sources (Linnell, 2011; Fleming et al., 2012; Mech, 2012). Most tests of the MRH, TCH and BMTCH have occurred in relatively intact ecosystems with relatively minor human footprints, such as the National Parks of Canada and the United States (Hebblewhite et al., 2005; Ray et al., 2005; Hayward and Somers, 2009; Eisenberg, 2011; Kuijper et al., 2017). Where studied, however, the strength and utility of carnivore effects on food webs in human-modified systems appear dissimilar to those in less modified ecosystems (e.g. Elmhagen et al., 2010; Muhly et al., 2013; Meadows et al., 2017; Morgan et al., 2017).

For example, the recolonization of wolves in Sweden resulted in widespread behaviour change by humans in their moose (Alces alces) hunting practices that precluded, or at least reduced, the anticipated numerical effects of wolves on moose (Wikenros et al., 2015). "Because 
most of the worlds' habitat that will be available for future colonization by large predators are likely to be strongly influenced by humans..., human response behaviour may constitute an important factor that ultimately may govern the impact of large predators on their prey and thus on potential trophic cascades" (Wikenros et al., 2015; pg. 18). This point is further underscored by the situation in South Africa, where the introduction or removal of large carnivores has largely been driven by economic incentives (Lindsey et al., 2007), and the long term ecological effects have been overlooked. In Kenya, the indirect effect of carnivores on tree communities was mediated by ranching practices and the spatial distribution of cattle corrals (Ford et al., 2014). Comparative analyses of mammalian food webs in protected areas versus human-dominated areas of Canada concluded that 'human influence on vegetation may strengthen bottom-up predominance and weaken top-down trophic cascades in ecosystems' and that 'human influences on ecosystems may usurp top-down and bottom-up effects' (Muhly et al., 2013).

Theories about the effects of large carnivores on food webs, as developed in relatively pristine areas, may not be readily transferable or applicable to the human-modified landscapes that make up the majority of the Earth's surface (Haswell et al., 2017; Morgan et al., 2017). This is because the direct and indirect effects of humans on all trophic levels may simply overshadow any carnivore effects (Muhly et al., 2013; Darimont et al., 2015; Clinchy et al., 2016; Kuijper et al., 2017). Carnivores are but one potential causal factor in a multicausal world (Vucetich and Peterson, 2004; Peterson et al., 2014; MacNulty et al., 2016; Engeman et al., 2017), and restoring large carnivores into these human-modified systems without removing the many other, more important causal factors influencing biodiversity loss is unlikely to succeed in reversing the situation (Allen and Fleming, 2012; Fleming et al., 2012). This is not to say that carnivore restoration efforts are unnecessary or should be avoided (Chapron et al., 2014), but that we should more carefully consider the anticipated benefits of these actions against the biophysical and anthropogenic factors that mediate the top-down effects of carnivores.

\section{Implications for large carnivore science and management}

The prevalence of these six aforementioned issues in the literature on large carnivores (Tables 1-3) underscores our contention that evidence for the MRH, TCH and BMTCH is undeniably weaker than is often claimed in journal articles or public discourse. Syntheses and literature reviews of large carnivores' ecological roles should identify these issues, but they usually do not, instead routinely failing to assess the internal validity of the original studies reviewed, as described by Bilotta et al. (2014). When the individual empirical studies that form the content of these reviews are judged against Platt's (1964) criteria for strong inference, Hone's (2007) deconstruction of experimental design capabilities, or Sutherland et al.' (2013) 20 tips for interpreting scientific claims, it is clear that even literature reviews (e.g. Ritchie and Johnson, 2009; Estes et al., 2011; Ripple et al., 2014b) seldom offer reliable guidance on the state of the literature addressing the MRH, TCH and BMTCH. These remain intriguing hypotheses, but they are each inadequately tested and not yet demonstrated for almost all large carnivores and contexts.

We fear that the debates about the issues we raise here (Tables 1-3) are heading towards the type of science denialism that plagues medicine or climate science (see Diethelm and McKee, 2009). In a growing number of cases, strong evidence against MRH, TCH and BMTCH is denied while promoting these hypotheses using tactics common to science denial in other disciplines, such as selectivity, use of logical fallacies, disregard of experimental work, and deference to correlations (for examples, see Letnic et al. 2011; Ripple et al., 2011; Beschta et al., 2014; Forsyth et al., 2014; Johnson et al., 2014; for responses, see Hodges, 2012; Squires et al., 2012; Fleming et al., 2013; Allen et al., 2014a; Winnie, 2014; Allen and West, 2015). Science denialism is often characterised by downplaying the scope of a threat (Russell and Blackburn, 2017). In the field of large carnivore science, this is clearly manifest in claims that carnivores are not a major problem for livestock producers or game ranchers (e.g. Forsyth et al., 2014). It is also manifest in claims that native large carnivores will suppress unwanted exotic species while denying that the same native carnivores can also suppress the threatened native species they are assumed to provide protection for (see Fleming et al., 2013 or Allen and Fleming, 2012 for discussion). Dismissing or downplaying the legitimacy of scientific criticisms as mere 'controversy' or 'debate' (e.g. Ritchie et al., 2014; Newsome et al., 2015) is also a form of passive science denialism. In truth, carnivores can have direct and indirect positive, negative or neutral impacts on social, economic and environmental values, and these impacts can change from time to time and place to place (Chamberlain et al., 2014; Haswell et al., 2017). But emphasizing 'the good' while downplaying 'the bad' only produces 'the ugly' literature on carnivore science, while also fostering the rise of invasive species science denialism (Russell and Blackburn, 2017). Such post-truth incredulities over evidence risks reversing progress in a field that is tackling some of the most important and engaging questions in modern ecology - namely, how does society restore and coexist with large fauna in human-occupied landscapes (LaRue et al., 2012; Chapron et al., 2014) and what may be the ecological outcomes of this restoration effort?

Debates about the scientific understanding of, and appropriate management response to, large carnivore impacts are not new. For example, in Alaska and northern Canada there has been an ongoing debate about the impact of wolf and grizzly bear (Ursus arctos) predation on moose and caribou (Rangifer tarandus) populations for decades (e.g. Orians et al., 1997; Kennedy and Fiorino, 2011). The discourse has centred on the extent to which lethal control of wolf and bear populations will lead to an increase in the harvestable surplus of moose and caribou. An enormous amount of intensive research, of both descriptive and experimental types (reviewed by Boertje et al., 2010), has been conducted in the region since the 1970's with the aim of understanding predatorprey relationships. But just like the Yellowstone region (MacNulty et al., 2016), there is still huge uncertainty and controversy about the nature of these trophic interactions and their consequences for management despite this considerable research investment (e.g. Van Ballenberghe, 2006; Boertje et al., 2010; Kennedy and Fiorino, 2011). Lessons that can be extracted from this ongoing saga include: (1) even with massive investment in research over many decades in relatively simple ecosystems it can still be a challenge to understand the nature of interactions between predators and prey, let alone the wider ecosystem impacts of human intervention on lower trophic levels; (2) valuable insights can be obtained by exploring such relationships through the lens of predator-prey theory and demographic models, an approach which has been almost absent from the recent generation of trophic cascade studies (Tables 1-3); and (3) competing scientific results can rapidly be included into what are essentially value debates about different worldviews. The maturation of this controversy clearly shows how important it is to be aware of the intrinsic uncertainty and context-dependence (in time and space) of any research results, and of the need to clearly distinguish science from values in policy debates.

There are, of course, studies that are not encumbered by the six issues we raise, studies that do indeed provide strong support for the MRH, TCH and BMTCH. Much of this can be found in literature from marine, aquatic and invertebrate systems (Heath et al., 2014; Meadows et al., 2017), or systems and models where bottom-up processes are relatively predictable, stable and controllable. Reliable work on $\mathrm{MRH}, \mathrm{TCH}$ and BMTCH in terrestrial systems is only beginning to catch up to these disciplines. Literature reviews and syntheses are important as the field develops, but as described above, most of the reviews presently available are inadequate. There is, therefore, an urgent need for a systematic review (sensu Pullin and Knight, 2009) of terrestrial studies that have used only manipulative experiments to investigate these hypotheses- experiments inclusive of paired treated and non-treated 
areas, sampled before and after treatments (e.g. carnivore removal or addition) over sufficient temporal and spatial scales to detect cascading responses of predators, prey and plants. A systematic review of such experimental studies, which excludes low-inference studies and summarises the results of only those with the actual capacity to assess causal processes, may produce useful insights into underlying ecological processes and be of great value to carnivore managers (Pullin and Knight, 2009; e.g. Boertje et al., 2010). It would also yield lessons on how to do more such research on different species, and in different contexts.

Many authors have called for such large-scale, long-term manipulative experiments investigating the removal or addition of large carnivores (e.g. Glen et al., 2007; Ritchie et al., 2012; Newsome et al., 2015). Although such experiments are expensive and difficult to achieve because of the logistical challenges arising from the massive scales that large carnivores utilise, they can and have been done in some places (e.g. Eldridge et al., 2002; Hayes et al., 2003; Hebblewhite et al., 2005; Allen et al., 2013a; Marshall et al., 2013; Allen et al., 2014b; Christianson and Creel, 2014; Ford et al., 2014; Hervieux et al., 2014; Ford et al., 2015b; Mitchell et al., 2015). These have often, but not always, shown support for elements of the MRH, TCH and BMTCH; less so for dingoes (Allen et al., 2014b) but more so for wolves (Winnie and Creel, 2017). It is unlikely that many large carnivores will be subject to experimental studies like these, or like the famous Kluane project on the Canada lynx (Lynx canadensis) and snowshoe hare (Lepus americanus) system (Krebs et al., 2001). As a consequence, it is highly unlikely that we will ever have access to knowledge from such experiments for most large carnivores. Thus, a systematic review of studies testing the MRH, TCH and BMTCH with only strongly-inferential methods will be all the more valuable. It must also be remembered that while well-designed and implemented experiments will greatly advance our understanding of theoretical ecological principles (Engeman et al., 2017), the portability of their results may still be limited (Schmitz et al., 2000; Haswell et al., 2017; Morgan et al., 2017).

Our focus on improving research rigour is not intended to imply that observational or correlative ecological studies are not useful. Such studies are absolutely crucial to capture the broad spatial and temporal dynamics over which large carnivores and their prey interact (Barley and Meeuwig, 2017). However, we argue that researchers need to exercise a greater degree of caution in the interpretation and communication of studies on the MRH, TCH and BMTCH, no matter how they are designed and conducted, and especially when they are used as the basis for radical changes in carnivore management and policy - including cases where lethal control and reintroduction are used. The associated biases, uncertainties, and ability to make inferences need to become ever more central parts of the communication of research results (Johnson et al., 2015). While we hope that scientists should manage this within the pages of peer-reviewed journals, additional challenges arise when trying to communicate uncertainty to the wider public (Dixon and Clarke, 2013). In such contexts it is normally impossible to successfully communicate such intrinsic limitations, making it all the more important that authors take extreme care to not oversell the generality of their findings, nor allow others to do so, and clearly separate between scientific findings and the various normative policy or management action contexts within which these findings might be operationalised.

The reality is that the knowledge available to wildlife managers will at best be limited to a solid understanding of the natural history and ecology of the predators, their prey, and the ecosystem, and based largely on data derived from time series, cross-site comparisons, 'natural experiments' or other correlative studies (Barley and Meeuwig, 2017; MacNulty et al., 2016). A good understanding of species ecology can serve to exclude spurious or unreasonable interpretations of correlative data, and such studies can also exclude certain hypotheses or provide indirect support for other hypotheses for which experiments could be designed to provide a definitive test (e.g. Platt, 1964; Kershaw, 1969; Underwood, 1997; Fairweather and Quinn, 2006). While these types of lower-inference studies may not overcome all the aforementioned issues we describe, they do have the advantage of being far cheaper and faster to conduct under a wide range of different ecological conditions, which can address problems associated with the transferability of knowledge between contexts. Ideally, conservation actions should be monitored within an adaptive management system that can be used to permit the study of system responses to specific management interventions (Fleming et al., 2014; Johnson et al., 2015). This provides insights into how the system functions and how management actions produce outcomes. Certain forms of carefully designed adaptive management exercises can even be viewed as quasi-experiments (Williams and Brown, 2014; Johnson et al., 2015).

Given the perilous conservation situation of many large carnivore species, there is a clear need to act based on the best available knowledge at any given time (Ripple et al., 2016a). However, manipulative experiments clearly trump anecdotal, observational and/or correlative information for their informative value, and should therefore be valued more highly in the decision making process (Platt, 1964; Fleming et al., 2013). While the weight of evidence for the general role of large carnivores in triggering trophic cascades is indeterminate at this time (but we look forward to this potentially changing one day), we caution researchers and science communicators to carefully consider the implications of simultaneously advocating for both large carnivore conservation and the primacy of top-down trophic cascades. These two forms of advocacy need not be linked - carnivore conservation can often be justified on a number of moral, ethical, and existential grounds that have nothing to do with trophic cascades. At one extreme, such advocacy may contribute towards baseless reintroduction efforts that divert funds from broader conservation goals and/or place the livelihoods of local people at risk (Ford et al., 2017). On the other extreme, we recognize that there will be no perfect study to ever 'close the book' on the prevalence of trophic cascades, regardless of their occurrence in nature. Because strongly-inferential, long-term, manipulative studies will be difficult to implement in a cost-effective and timely manner to support these decisions, we argue that knowledge of trophic cascades must be considered in management deliberations but should not necessarily determine their outcome.

Whether or not society should or shouldn't restore large carnivores is outside the scope of our present analysis (but see Lewis et al., 2017), and in the end, how large carnivores are managed is a judgement that society must make, and which will largely be based on which species (predator or prey or human interest) is given priority over another. In the Canadian case of Hervieux et al. (2014), for example, the immediate interests of ungulates were ultimately favoured over those of the wolves. Whereas, in the familiar Yellowstone story (e.g. Middleton, 2014), the interests of wolves were ultimately favoured over those of the ungulates. Whether large carnivores are viewed as a 'good thing' or a 'bad thing' for an ecosystem largely rests on the attention given to which species (livestock, invasive pests, game species or threatened native fauna) carnivores happen to be killing at the time (Allen et al., 2011b; Mech, 2012). As carnivore conservationists ourselves, we relish any excuse to promote their conservation and recovery where it is needed and possible. But as scientists, we lament the lack of objectivity and critical thinking underpinning the current 'parental affection' (sensu Chamberlin, 1890) towards the MRH, TCH, and BMTCH and the extent to which this affection is used to legitimise selected views on carnivore management.

Upon reflection, we also observe that debates about large carnivore management (Tables 1-3) are often not so much about differing beliefs or views about carnivores' actual functional roles, but more so about the quality of scientific evidence people are willing to accept. Large carnivore conservation is a bold and historically-novel judgement which must inevitably be made on incomplete ecological evidence. Ecological evidence alone is insufficient to make decisions, which must also account for the ethical, cultural and socio-political factors that shape decision making in society (e.g. Van Ballenberghe, 2006; Mech, 2010; 
Trouwborst, 2010; Fleming et al., 2014; Olson et al., 2015; Trouwborst, 2015; Marshall et al., 2016; Lewis et al., 2017). We hope that the issues we raise here prompt deeper consideration of actual evidence, leading to an improvement in both the rigour and communication of large carnivore science, because the fates of many large carnivores and the integrity of associated ecological processes are depending on it.

\section{Acknowledgments}

Carl Mitchell, John Winnie, Stewart Breck and Tom Hobbs contributed discussion points and provided helpful comments and suggestions on earlier drafts of the manuscript. John Linnell was funded by the Research Council of Norway (Grant \#251112).

\section{References}

Allen, B.L., 2010. Did dingo control cause the elimination of kowaris through mesopredator release effects? A response to Wallach and O'Neill (2009). Anim. Biodivers. Conserv. 33 (2), 1-4.

Allen, B.L., 2011. A comment on the distribution of historical and contemporary livestock grazing across Australia: implications for using dingoes for biodiversity conservation. Ecol. Manag. Restor. 12 (1), 26-30.

Allen, B.L., 2012a. Do desert dingoes drink daily? Visitation rates at remote waterpoints in the Strzelecki Desert. Aust. Mammal. 34 (2), 251-256.

Allen, B.L., 2012b. Scat happens: spatiotemporal fluctuation in dingo scat collection rates. Aust. J. Zool. 60 (2), 137-140.

Allen, B.L., 2015a. More buck for less bang: reconciling competing wildlife management interests in agricultural food webs. Food Webs 2,1-9.

Allen, B.L., 2015b. Top-predator control-induced trophic cascades: an alternative hypothesis to the conclusion of Colman et al. (2014). Proc. R. Soc. B 282 (1799), 1-3.

Allen, B.L., Fleming, P.J.S., 2012. Reintroducing the dingo: the risk of dingo predation to threatened vertebrates of western New South Wales. Wildl. Res. 39 (1), 35-50.

Allen, B.L., Leung, L.K.-P., 2012. Assessing predation risk to threatened fauna from their prevalence in predator scats: dingoes and rodents in arid Australia. PLoS One 7 (5), e36426.

Allen, B.L., West, P., 2013. The influence of dingoes on sheep distribution in Australia. Aust. Vet. J. 91, 261-267.

Allen, B.L., West, P., 2015. Dingoes are a major causal factor for the decline and distribution of sheep in Australia. Aust. Vet. J. 93 (4), 90-92.

Allen, B.L., Engeman, R.M., Allen, L.R., 2011a. Wild dogma I: an examination of recent "evidence" for dingo regulation of invasive mesopredator release in Australia. Curr. Zool. 57 (5), 568-583.

Allen, B.L., Engeman, R.M., Allen, L.R., 2011b. Wild dogma II: the role and implications of wild dogma for wild dog management in Australia. Curr. Zool. 57 (6), 737-740.

Allen, B.L., Allen, L.R., Engeman, R.M., Leung, L.K.-P., 2013a. Intraguild relationships between sympatric predators exposed to lethal control: predator manipulation experiments. Front. Zool. 10, 39

Allen, B.L., Fleming, P.J.S., Allen, L.R., Engeman, R.M., Ballard, G., Leung, L.K.-P., 2013b. As clear as mud: a critical review of evidence for the ecological roles of Australian dingoes. Biol. Conserv. 159, 158-174.

Allen, B.L., Allen, L.R., Engeman, R.M., Leung, L.K.-P., 2014a. Reply to the criticism by Johnson et al. (2014) on the report by Allen et al. (2013). Front. Zool. (accessed 1st June 2014, Available at: http://www.frontiersinzoology.com/content/11/11/17/ comments\#1982699).

Allen, B.L., Allen, L.R., Engeman, R.M., Leung, L.K.-P., 2014b. Sympatric prey responses to lethal top-predator control: predator manipulation experiments. Front. Zool. 11, 56

Allen, B.L., Lundie-Jenkins, G., Burrows, N.D., Engeman, R.M., Fleming, P.J.S., Leung, L.K.-P., 2014c. Does lethal control of top-predators release mesopredators? A re-evaluation of three Australian case studies. Ecol. Manag. Restor. 15 (3), 191-195.

Allen, B.L., Allen, L.R., Leung, K.-P., 2015. Interactions between two naturalised invasive predators in Australia: are feral cats suppressed by dingoes? Biol. Invasions 17, $761-776$.

Allen, L.R., 2014. Wild dog control impacts on calf wastage in extensive beef cattle enterprises. Anim. Prod. Sci. 54 (2), 214-220.

Allen, L.R., 2017. Is landscape-scale wild dog control best practice? Aust. J. Environ. Manag. $\mathrm{xx}$ (xx-xx).

Allen, L.R., Engeman, R.M., 2014. Evaluating and validating abundance monitoring methods in the absence of populations of known size: review and application to a passive tracking index. Environ. Sci. Pollut. Res. 22, 2907-2915.

Anahita, S., Mix, T.L., 2006. Retrofitting frontier masculinity for Alaska's war against wolves. Gend. Soc. 20 (3), 332-353.

Armstrong, D., Hayward, M., Moro, D., Seddon, P., 2015. Advances in Reintroduction Biology of Australian and New Zealand Fauna. CSIRO Publishing, Melbourne.

Bannister, H., 2014. Factors Influencing the Reintroduction Success of the Burrowing Bettong (Bettongia lesueur) to Arid Australia. Honours thesis. The University of Western Australia.

Bannister, H.L., Lynch, C.E., Moseby, K.E., 2016. Predator swamping and supplementary feeding do not improve reintroduction success for a threatened Australian mammal, Bettongia lesueur. Australian mammalogy 38, 177-187.

Barber-Meyer, S.M., 2015. Trophic cascades from wolves to grizzly bears or changing abundance of bears and alternate foods? J. Anim. Ecol. 84 (3), 647-651.
Barbosa, P., Castellanos, I., 2005. Ecology of Predator-Prey Interactions. New York, Oxford University Press.

Barley, S.C., Meeuwig, J.J., 2017. The power and the pitfalls of large-scale, unreplicated natural experiments. Ecosystems 20, 331-339.

Barnes, T.S., Goldizen, A.W., Morton, J.M., Coleman, G.T., 2008. Cystic echinococcosis in a wild population of the brush-tailed rock-wallaby (Petrogale penicillata), a threatened macropodid. Parasitology 135, 715-723.

Beschta, R.L., Ripple, W.J., 2007. Increased willow heights along northern Yellowstone's blacktail deer creek following wolf reintroduction. West. North Am. Natural. 67 (4), 613-617.

Beschta, R.L., Ripple, W.J., 2010. Mexican wolves, elk, and aspen in Arizona: is there a trophic cascade? For. Ecol. Manag. 260 (5), 915-922.

Beschta, R.L., Ripple, W.J., 2013. Are wolves saving Yellowstone's aspen? A landscapelevel test of a behaviorally mediated trophic cascade: comment. Ecology 94 (6) 1420-1425.

Beschta, R.L., Eisenberg, C., Laundré, J.W., Ripple, W.J., Rooney, T.P., 2014. Predation risk, elk, and aspen: comment. Ecology 95 (9), 2669-2671.

Beyer, H.L., Merrill, E.H., Varley, N., Boyce, M.S., 2007. Willow on Yellowstone's northern range: evidence for a trophic cascade? Ecol. Appl. 17, 1563-1571.

Bilotta, G., Milner, A., Boyd, I., 2014. Quality assessment tools for evidence from environmental science. Environ. Evid. 3 (1), 14.

Bilyeu, D.M., Cooper, D.J., Hobbs, N.T., 2008. Water tables constrain height recovery of willow on Yellowstone's northern range. Ecol. Appl. 18 (1), 80-92.

Bird, P., 1994. Improved Electric Fences and Baiting Techniques: A Behavioural Approach to Integrated Dingo Control. Animal and Plant Control Commission, Department of Primary Industries South Australia, Adelaide.

Boertje, R.D., Valkenburg, P., McNay, M.E., 1996. Increases in moose, caribou, and wolves following wolf control in Alaska. J. Wildl. Manag. 60 (3), 474-489.

Boertje, R.D., Keech, M.A., Paragi, T.F., 2010. Science and values influencing predator control for Alaska moose management. J. Wildl. Manag. 74 (5), 917-928.

Bowyer, R.T., Person, D.K., Pierce, B.M., 2005. Detecting top-down versus bottom-up regulation of ungulates by large carnivores: implications for conservation of biodiversity. In: Ray, J.C., Redford, K.H., Steneck, R.S., Berger, J. (Eds.), Large Carnivores and the Conservation of Biodiversity. Island Press, Washington, pp. 342-361.

Bradshaw, C.J.A., Sodhi, N.S., Laurance, W.F., Brook, B.W., 2011. Twenty landmark papers in biodiversity conservation. In: Pavlinov, I.Y. (Ed.), Research in Biodiversity - Models and Applications. InTech, Rijeka, Crotia, pp. 97-112.

Brawata, R.L., Neeman, T., 2011. Is water the key? Dingo management, intraguild interactions and predator distribution around water points in arid Australia. Wildl. Res. 38 (5), 426-436.

Braysher, M., 1993. Managing Vertebrate Pests: Principles and Strategies. Bureau of Rural Sciences, Australian Government Publishing, Canberra.

Brodie, J.F., Giordano, A., 2013. Lack of trophic release with large mammal predators and prey in Borneo. Biol. Conserv. 63, 58-67.

Brodie, J.F., Giordano, A.J., Zipkin, E.F., Bernard, H., Mohd-Azlan, J., Ambu, L., 2014 Correlation and persistence of hunting and logging impacts on tropical rainforest mammals. Conserv. Biol. 29, 110-121.

Carwardine, J., O'Connor, T., Legge, S., Mackey, B., Possingham, H.P., Martin, T.G., 2012. Prioritizing threat management for biodiversity conservation. Conserv. Lett. 5 (3), 196-204.

Caughley, G., 1980. Analysis of Vertebrate Populations (Reprinted With Corrections edn) John Wiley \& Sons Ltd, Chichester.

Chamberlain, S.A., Bronstein, J.L., Rudgers, J.A., 2014. How context dependent are species interactions? Ecol. Lett. 17 (7), 881-890.

Chamberlin, T.C., 1890. The method of multiple working hypotheses. Science 15, 92-96 (reprinted in Science 148:154-759, 1965).

Chapron, G., Lopez-Bao, J.V., 2014. Conserving carnivores: politics in play. Science 343, 1199-1200.

Chapron, G., Kaczensky, P., Linnell, J.D.C., von Arx, M., Huber, D., Andrén, H., LópezBao, J.V., Adamec, M., Álvares, F., Anders, O., Balčiauskas, L., Balys, V., Bedő, P. Bego, F., Blanco, J.C., Breitenmoser, U., Brøseth, H., Bufka, L., Bunikyte, R., Ciucci, P., Dutsov, A., Engleder, T., Fuxjäger, C., Groff, C., Holmala, K., Hoxha, B., Iliopoulos, Y., Ionescu, O., Jeremić, J., Jerina, K., Kluth, G., Knauer, F., Kojola, I., Kos, I., Krofel, M., Kubala, J., Kunovac, S., Kusak, J., Kutal, M., Liberg, O., Majić, A., Männil, P., Manz, R., Marboutin, E., Marucco, F., Melovski, D., Mersini, K., Mertzanis, Y., Mysłajek, R.W., Nowak, S., Odden, J., Ozolins, J., Palomero, G., Paunović, M., Persson, J., Potočnik, H., Quenette, P.-Y., Rauer, G., Reinhardt, I. Rigg, R., Ryser, A., Salvatori, V., Skrbinšek, T., Stojanov, A., Swenson, J.E., Szemethy, L., Trajçe, A., Tsingarska-Sedefcheva, E., Váňa, M., Veeroja, R., Wabakken, P., Wölfl, M., Wölfl, S., Zimmermann, F., Zlatanova, D., Boitani, L., 2014. Recovery of large carnivores in Europe's modern human-dominated landscapes. Science 346 (6216), 1517-1519.

Christensen, P., Burrows, N., 1995. Project Desert Dreaming: experimental reintroduction of mammals to the Gibson Desert, Western Australia. In: Serena, M. (Ed), Reintroduction Biology of Australian and New Zealand Fauna. Surrey Beatty \& Sons, Chipping Norton, pp. 199-207.

Christianson, D., Creel, S., 2014. Ecosystem scale declines in elk recruitment and population growth with wolf colonization: a before-after-control-impact approach. PLoS One 9 (7), e102330.

Claridge, A.W., 2013. Examining interactions between dingoes (wild dogs) and mesopredators: the need for caution when interpreting summary data from previously published work. Aust. Mammal. 35 (2), 248-250.

Clinchy, M., Zanette, L.Y., Roberts, D., Suraci, J.P., Buesching, C.D., Newman, C., Macdonald, D.W., 2016. Fear of the human "super predator" far exceeds the fear of large carnivores in a model mesocarnivore. Behav. Ecol. 27 (6), 1826-1832. 
Colman, N.J., Gordon, C.E., Crowther, M.S., Letnic, M., 2014. Lethal control of an apex predator has unintended cascading effects on forest mammal assemblages. Proc. R. Soc. B Biol. Sci. 281 (1782), 20133094

Colman, N.J., Gordon, C.E., Crowther, M.S., Letnic, M., 2015. Response to Allen 'An alternative hypothesis to the conclusion of Colman et al. (2014). Proc. R. Soc. B 282 (1799), xx.

Cooke, B.D., Soriguer, R.C., 2017. Do dingoes protect Australia's small mammal fauna from introduced mesopredators? Time to consider history and recent events. Food Webs 12, 94-105.

Corbett, L.K., 2001. The Dingo in Australia and Asia. second ed. J.B. Books, South Australia, Marleston.

Creel, S., Christianson, D., 2009. Wolf presence and increased willow consumption by Yellowstone elk: implications for trophic cascades. Ecology 90 (9), 2454-2466

Creel, S., Winnie, J., Maxwell, B., Hamlin, K., Creel, M., 2005. Elk alter habitat selection as an antipredator response to wolves. Ecology 86 (12), 3387-3397.

Crooks, K.R., Soulé, M.E., 1999. Mesopredator release and avifaunal extinctions in fragmented system. Nature 400, 563-566.

Darimont, C.T., Fox, C.H., Bryan, H.M., Reimchen, T.E., 2015. The unique ecology of human predators. Science 349, 858-860.

Darwin, C., 1859. On the Origin of Species by Means of Natural Selection, or the Preservation of Favoured Races in the Struggle for Life. sixth ed. John Murray, London.

Despain, D., 2005. Alternative Hypothesis for Willow Growth. Proceedings of the 8th Biennial Scientific Conference on the Greater Yellowstone Ecosystem. Yellowstone National Park, Wyoming.

Dickman, C., Glen, A., Letnic, M., 2009. Reintroducing the dingo: can Australia's conservation wastelands be restored? In: Hayward, MW Somers, MJ. (Eds.), Reintroduction of top-order Predators. Wiley-Blackwell, Oxford, pp. 238-269

Diethelm, P., McKee, M., 2009. Denialism: what is it and how should scientists respond? Eur. J. Public Health 19 (1), 2-4.

Dixon, G.N., Clarke, C.E., 2013. Heightening uncertainty around certain science: media coverage, false balance, and the autism-vaccine controversy. Sci. Commun. 35 358-382.

Doherty, T.S., Ritchie, E.G., 2017. Stop jumping the gun: a call for evidence-based invasive predator management. Conserv. Lett. 10, 15-22.

Dorresteijn, I., Schultner, J., Nimmo, D.G., Fischer, J., Hanspach, J., Kuemmerle, T., Kehoe, L. Ritchie, E.G., 2015. Incorporating anthropogenic effects into trophic ecology: predator-prey interactions in a human-dominated landscape. Proc. R. Soc. B 282, 1814

East, I.J., Foreman, I., 2011. The structure, dynamics and movement patterns of the Australian sheep industry. Aust. Vet. J. 89 (12), 477-489.

Eisenberg, C., 2011. The wolf's Tooth: Keystone Predators, top Predators, Trophic Cascades, and Biodiversity. Island Press, Washington D.C.

Eisenberg, C., Seager, S.T., Hibbs, D.E., 2013. Wolf, elk, and aspen food web relationships: context and complexity. For. Ecol. Manag. 299, 70-80.

Eldridge, S.R., Shakeshaft, B.J., Nano, T.J., 2002. The impact of wild dog control on cattle, native and introduced herbivores and introduced predators in central Australia. Final Report to the Bureau of Rural Sciences'. Parks and Wildlife Commission of the Northern Territory. Alice Springs.

Elmhagen, B., Rushton, S.P., 2007. Trophic control of mesopredators in terrestria ecosystems: top-down or bottom-up? Ecol. Lett. 10, 197-206.

Elmhagen, B., Ludwig, G., Rushton, S.P., Helle, P., Linden, H., 2010. Top predators, mesopredators and their prey: interference ecosystems along bioclimatic productivity gradients. J. Anim. Ecol. 79, 785-794

Engeman, R., 2005. Indexing principles and a widely applicable paradigm for indexing animal populations. Wildl. Res. 32 (3), 202-210.

Engeman, R.M., Allen, L.R., Allen, B.L., 2017. Study design concepts for inferring functional roles of mammalian top predators. Food Webs 12, 55-62.

Estes, J.A., Terborgh, J., Brashares, J.S., Power, M.E., Berger, J., Bond, W.J., Carpenter, S.R Essington, T.E., Holt, R.D., Jackson, J.B.C., Marquis, R.J., Oksanen, L., Oksanen, T. Paine, R.T., Pikitch, E.K., Ripple, W.J., Sandin, S.A., Scheffer, M., Schoener, T.W. Shurin, J.B., Sinclair, A.R.E., Soulé, M.E., Virtanen, R., Wardle, D.A., 2011. Trophic downgrading of planet earth. Science 333, 301-306.

Fairweather, P., Quinn, G., 2006. Design of sampling and experiments in ecology. In: Attiwill, P., Wilson, B. (Eds.), Ecology: An Australian Perspective. Oxford University Press, Melbourne.

Fillios, M., Gordon, C., Koch, F., Letnic, M., 2010. The effect of a top predator on kangaroo abundance in arid Australia and its implications for archaeological faunal assemblages. J. Archaeol. Sci. 37 (5), 986-993.

Finke, D.L., Denno, R.F., 2004. Predator diversity dampens trophic cascades. Nature 429 (6990), 407-410.

Fitzsimmons, K.E., 2007. Morphological variability in the linear dunefields of the Strzelecki and Tirari Deserts, Australia. Geomorphology 91 (1-2), 146-160.

Flagel, D.G., Belovsky, G.E., Cramer, M.J., Beyer, D.E., Robertson, K.E., 2017. Fear and loathing in a Great Lakes forest: cascading effects of competition between wolves and coyotes. J. Mammal. 98, 77-84.

Fleming, P.J.S., Allen, B.L., Ballard, G., 2012. Seven considerations about dingoes as biodiversity engineers: the socioecological niches of dogs in Australia. Aust. Mammal. 34 (1), 119-131.

Fleming, P.J.S., Allen, B.L., Ballard, G., 2013. Cautionary considerations for positive dingo management: a response to the Johnson and Ritchie critique of Fleming et al (2012). Aust. Mammal. 35 (1), 15-22.

Fleming, P.J.S., Allen, B.L., Allen, L.R., Ballard, G., Bengsen, A.J., Gentle, M.N., McLeod, L.J. Meek, P.D., Saunders, G.R., 2014. Management of wild canids in Australia: free-ranging dogs and red foxes. In: Glen, A.S., Dickman, C.R. (Eds.), Carnivores of Australia: Past, Present and Future. CSIRO Publishing, Collingwood, pp. 105-149.

Ford, A.T., Goheen, J.R., 2015. Trophic cascades by large carnivores: a case for strong inference and mechanism. Trends Ecol. Evol. 30 (12), 725-735.
Ford, A.T., Goheen, J.R., Otieno, T.O., Bidner, L., Isbell, L.A., Palmer, T.M., Ward, D., Woodroffe, R., Pringle, R.M., 2014. Large carnivores make savanna tree communities less thorny. Science 346 (6207), 346-349.

Ford, A.T., Goheen, J.R., Augustine, D.J., Kinnaird, M.F., O'Brien, T.G., Palmer, T.M., Pringle, R.M., Woodroffe, R., 2015a. Recovery of African wild dogs suppresses prey but does not trigger a trophic cascade. Ecology 96, 2705-2714.

Ford, A.T., Goheen, J.R., Augustine, D.J., Kinnaird, M.F., O'Brien, T.G., Palmer, T.M., Pringle, R.M., Woodroffe, R., 2015b. Recovery of African wild dogs suppresses prey but does not trigger a trophic cascade. Ecology 96 (10), 2705-2714.

Ford, A.T., Cook, S.J., Goheen, J.J., Young, T., 2017. Conserving megafauna or sacrificing biodiversity? Bioscience (in press)

Forsyth, D.M., Woolnough, A.P., Nimmo, D.G., Ritchie, E.G., Kennedy, M., Pople, A., Watson, I., 2014. A comment on the influence of dingoes on the Australian sheep flock. Aust. Vet. J. 92 (12), 461-462.

Gasaway, W.C., Stephenson, R.O., Davis, J.L., Shepherd, P.E.K., Burris, O.E., 1983. Interrelationships of wolves, prey, and man in interior Alaska. Wildl. Monogr. 84, 1-50.

Glen, A.S., 2012. Enough dogma: seeking the middle ground on the role of dingoes. Curr. Zool. 58 (6), 856-858.

Glen, A.S., Woodman, A.P., 2013. What Impact Does Altering Dingo Populations Have on Trophic Structure? Environmental Evidence Australia, Newcastle

Glen, A.S., Dickman, C.R., Soulé, M.E., Mackey, B.G., 2007. Evaluating the role of the dingo as a trophic regulator in Australian ecosystems. Aust. Ecol. 32 (5), 492-501.

Gordon, C.E., Eldridge, D.J., Ripple, W.J., Crowther, M.S., Moore, B.D., Letnic, M., 2017a. Shrub encroachment is linked to extirpation of an apex predator. J. Anim. Ecol. 86 (1), 147-157.

Gordon, C.E., Moore, B.D., Letnic, M., 2017b. Temporal and spatial trends in the abundances of an apex predator, introduced mesopredator and ground-nesting bird are consistent with the mesopredator release hypothesis. Biodivers. Conserv. $\mathrm{xx}$ (xx-xx).

Hairston, N., Smith, F., Slobodkin, L., 1960. Community structure, population control and competition. Am. Nat. 94, 421-425.

Haswell, P.M., Kusak, J., Hayward, M.W., 2017. Large carnivore impacts are context-dependent. Food Webs 12, 2-12.

Hayes, R.D., Farnell, R., Ward, R.M.P., Carey, J., Dehn, M., Kuzyk, G.W., Baer, A.M., Gardner, C.L., O'Donoghue, M., 2003. Experimental reduction of wolves in the Yukon: ungulate responses and management implications. Wildl. Monogr. 152, 1-35.

Hayward, M., 2012. Time to agree on a conservation benchmark for Australia. Pac. Conserv. Biol. 18, 69-76.

Hayward, M.W., Marlow, N., 2014. Will dingoes really conserve wildlife and can our methods tell? J. Appl. Ecol. 51 (4), 835-838.

Hayward, M.W., Somers, M.J., 2009. Reintroduction of top-order Predators. WileyBlackwell, Oxford.

Hayward, M.W., Boitani, L., Burrows, N.D., Funston, P.J., Karanth, K.U., MacKenzie, D.I., Pollock, K.H., Yarnell, R.W., 2015. Ecologists need robust survey designs, sampling and analytical methods. J. Appl. Ecol. 52 (2), 286-290.

Heath, M.R., Speirs, D.C., Steele, J.H., 2014. Understanding patterns and processes in models of trophic cascades. Ecol. Lett. 17 (1), 101-114.

Hebblewhite, M., White, C.A., Nietvelt, C.G., McKenzie, J.A., Hurd, T.E., Fryxell, J.M., Bayley, S.E., Paquet, P.C., 2005. Human activity mediates a trophic cascade caused by wolves. Ecology 86 (8), 2135-2144.

Helldin, J.O., Liberg, O., Glöersen, G., 2006. Lynx (Lynx lynx) killing red foxes (Vulpes vulpes) in boreal Sweden - frequency and population effects. J. Zool. 270 (4), 657-663.

Hervieux, D., Hebblewhite, M., Stepnisky, D., Bacon, M., Boutin, S., 2014. Managing wolves (Canis lupus) to recover threatened woodland caribou (Rangifer tarandus caribou) in Alberta. Can. J. Zool. 92 (12), 1029-1037.

Hodges, K.E., 2012. Data-free speculation does not make for testable hypotheses: a reply to Ripple et al. Wildl. Soc. Bull. 36 (3), 561-566.

Holt, R.D., Huxel, G.R., 2007. Alternative prey and the dynamics of intraguild predation: theoretical perspectives. Ecology 88 (11), 2706-2712.

Hone, J., 2007. Wildlife Damage Control. CSIRO Publishing, Collingwood, Victoria.

Hone, J., Drake, A., Krebs, C., 2015. Prescriptive and empirical principles of applied ecology. Environ. Rev. 23 (2), 170-176.

Howland, B., Stojanovic, D., Gordon, I.J., Manning, A.D., Fletcher, D., Lindenmayer, D.B., 2014. Eaten out of house and home: impacts of grazing on ground-dwelling reptiles in Australian grasslands and grassy woodlands. PLoS One 9 (12), e105966.

Ioannidis, J.P.A., 2005. Why most published research findings are false. PLoS Med. 2 (8), e124.

Ioannidis, J.P.A., 2014. How to make more published research true. PLoS Med. 11 (10), e1001747.

Johnson, C., 2006. Australia's Mammal Extinctions: A 50,000 year History. Cambridge University Press, Melbourne.

Johnson, C.N., Ritchie, E., 2013. The dingo and biodiversity conservation: response to Fleming et al. (2012). Aust. Mammal. 35 (1), 8-14

Johnson, C.J., Wallach, A.D., 2016. The virtuous circle: predator-friendly farming and ecological restoration in Australia. Restor. Ecol. 24, 821-826.

Johnson, C.N., Isaac, J.L., Fisher, D.O., 2007. Rarity of a top predator triggers continent-wide collapse of mammal prey: dingoes and marsupials in Australia. Proc. R. Soc. B Biol. Sci. B 274 (1608), 341-346.

Johnson, C.N., Crowther, M.S., Dickman, C.R., Letnic, M.I., Newsome, T.M., Nimmo, D.G., Ritchie, E.G., Wallach, A.D., 2014. Experiments in no-impact control of dingoes: comment on Allen et al. 2013. Front. Zool. 11, 17.

Johnson, F.A., Eaton, M.J., Williams, J.H., Jensen, G.H., Madsen, J., 2015. Training conservation practitioners to be better decision makers. Sustainability 7, 8354-8373.

Johnston, D.B., Cooper, D.J., Hobbs, N.T., 2011. Relationships between groundwater use, water table, and recovery of willow on Yellowstone's northern range. Ecosphere 2 (2), 1-11. 
Jones, K.R., 2002. Wolf Mountains: A History of Wolves Along the Great Divide. University of Calgary Press, Calgary, Canada.

Kauffman, M.J., Varley, N., Smith, D.W., Stahler, D.R., MacNulty, D.R., Boyce, M.S., 2007. Landscape heterogeneity shapes predation in a newly restored predator-prey system. Ecol. Lett. 10 (8), 690-700.

Kauffman, M.J., Brodie, J.F., Jules, E.S., 2010. Are wolves saving Yellowstone's aspen? A landscape-level test of a behaviorally mediated trophic cascade. Ecology 91, 2742-2755.

Kauffman, M.J., Brodie, J.F., Jules, E.S., 2013. Are wolves saving Yellowstone's aspen? A landscape-level test of a behaviorally mediated trophic cascade: reply. Ecology 94 (6), 1425-1431.

Kendall, B.E., 2015. Some directions in ecological theory. Ecology 96, 3117-3125.

Kennedy, C., Fiorino, T., 2011. Alaska's Predator Control Programs: Managing for Abundance or Abundant Mismanagement? Defenders of Wildlife, Washington DC

Kerle, J.A., Foulkes, J.N., Kimber, R.G., Papenfus, D., 1992. The decline of the brushtail possum, Trichosurus vulpecula (Kerr 1798), in arid Australia. Rangel. J. 14 (2), 107-127.

Kershaw, K.A., 1969. Quantitative and Dynamic Ecology. Edward Arnold Publishers, London.

Kimble, D.S., Tyers, D.B., Robison-Cox, J., Sowell, B.F., 2011. Aspen recovery since wolf reintroduction on the northern Yellowstone winter range. Rangel. Ecol. Manag. 64 (2), 119-130.

Koerner, S.E., Collins, S.L., 2014. Interactive effects of grazing, drought, and fire on grassland plant communities in North America and South Africa. Ecology 95 (1), 98-109.

Kowalczyk, R., Zalewski, A., Jędrzejewska, B., Ansorge, H., Bunevich, A.N., 2009. Reproduction and mortality of invasive raccoon dogs (Nyctereutes procyonoides) in the Białowieża Primeval Forest (eastern Poland). Ann. Zool. Fenn. 46 (4), 291-301.

Krebs, C.J., 2008. Ecology: The Experimental Analysis of Distribution and Abundance. 6 ed. Benjamin-Cummings Publishing, San Francisco.

Krebs, C.J., Boonstra, R., Boutin, S., Sinclair, A.R.E., 2001. What drives the 10-year cycle of snowshoe hares? Bioscience 51 (1), 25-35.

Kueffer, C., Kaiser-Bunbury, C.N., 2013. Reconciling conflicting perspectives for biodiversity conservation in the Anthropocene. Front. Ecol. Environ. 12,131-137.

Kuijper, D.P.J., 2011. Lack of natural control mechanisms increases wildlife-forestry conflict in managed temperate European forest systems. Eur. J. For. Res. 130 (6), 895.

Kuijper, D.P.J., Bubnicki, J.W., Churski, M., Cromsigt, J.P.G.M., 2016. Multi-trophic interactions in anthropogenic landscapes: the devil is in the detail. Proc. R. Soc. B Biol. Sci. 283, 1834.

Kuijper, D.P.J., Sahlén, E., Elmhagen, B., Chamaillé-Jammes, S., Sand, H., Lone, K., et al., 2017. Paws without claws? Ecological effects of large carnivores in anthropogenic landscapes. Proc. R. Soc. B Biol. Sci. 283 (in press)

LaRue, M.A., Nielsen, C.K., Dowling, M., Miller, K., Wilson, B., Shaw, H., Anderson, C.R., 2012. Cougars are recolonizing the Midwest: analysis of cougar confirmations during 1990-2008. J. Wildl. Manag. 76 (7), 1364-1369.

Leopold, A., 1949. A Sand County Almanac: With Other Essays on Conservation From Round River. Oxford University Press, New York.

Letnic, M., Koch, F., 2010. Are dingoes a trophic regulator in arid Australia? A comparison of mammal communities on either side of the dingo fence. Aust. Ecol. 35 (2), 267-1175.

Letnic, M., Crowther, M., Koch, F., 2009. Does a top-predator provide an endangered rodent with refuge from a mesopredator? Anim. Conserv. 12 (4), 302-312.

Letnic, M., Crowther, M.S., Dickman, C.R., Ritchie, E., 2011. Demonising the dingo: how much wild dogma is enough? Current Zoology 57 (5), 668-670.

Letnic, M., Ritchie, E.G., Dickman, C.R., 2012. Top predators as biodiversity regulators: the dingo Canis lupus dingo as a case study. Biol. Rev. 87 (2), 390-413.

Letnic, M., Baker, L., Nesbitt, B., 2013. Ecologically functional landscapes and the role of dingoes as trophic regulators in south-eastern Australia and other habitats. Ecol. Manag. Restor. 14 (2), 101-105.

Lewis, P.-M., Burns, G.L., Jones, D., 2017. Response and responsibility: humans as apex predators and ethical actors in a changing societal environment. Food Webs 12 48-54.

Lindsey, P.A., Roulet, P.A., Romañach, S.S., 2007. Economic and conservation significance of the trophy hunting industry in sub-Saharan Africa. Biol. Conserv. 134 (4), 455-469.

Linnell, J.D.C., 2011. The relative importance of predators and people in structuring and conserving ecosystems. Conserv. Biol. 25 (3), 646-647.

Linnell, J.D.C., Strand, O., 2002. Do arctic foxes Alopex lagopus depend on kills made by large predators? Wildl. Biol. 8, 69-75.

Lundie-Jenkins, G., Lowry, J., 2005. Recovery Plan for the Bridled Nailtail Wallaby (Onychogalea fraenata) 2005-2009: Report to the Department of Environment and Heritage (DEH), Canberra. Environmental Protection Agency/Queensland Parks and Wildlife Service, Brisbane.

MacNulty, D.R., Stahler, D.R., Wyman, C.T., Ruprecht, J., Smith, D.W., 2016. The challenge of understanding northern Yellowstone elk dynamics after wolf reintroduction. Yellowstone Sci. 24 (1), 25-33.

Maron, J.L., Pearson, D.E., 2011. Vertebrate predators have minimal cascading effects on plant production or seed predation in an intact grassland ecosystem. Ecol. Lett. 14 (7), 661-669.

Marris, E., 2014. Rethinking predators: legend of the wolf. Nature 507, 158-160.

Marshall, K.N., Hobbs, N.T., Cooper, D.J., 2013. Stream hydrology limits recovery of riparian ecosystems after wolf reintroduction. Proc. R. Soc. B 280, 1756

Marshall, K.N., Cooper, D.J., Hobbs, N.T., 2014. Interactions among herbivory, climate, topography and plant age shape riparian willow dynamics in northern Yellowstone National Park, USA. J. Ecol. 102 (3), 667-677.

Marshall, K.N., Stier, A.C., Samhouri, J.F., Kelly, R.P., Ward, E.J., 2016. Conservation challenges of predator recovery. Conserv. Lett. 9 (1), 70-78.
McCoy, M.W., Stier, A.C., Osenberg, C.W., 2012. Emergent effects of multiple predators on prey survival: the importance of depletion and the functional response. Ecol. Lett. 15, 1449-1456

McPeek, M.A., 2014. Keystone and intraguild predation, intraspecific density dependence, and a guild of coexisting consumers. Am. Nat. 183 (1), E1-E16.

Meadows, A.J., Crowder, D.W., Snyder, W.E., 2017. Are wolves are just wasps with teeth? What invertebrates can teach us about mammal top-predators. Food Webs 12 39-47.

Mech, L.D., 2010. Considerations for developing wolf harvesting regulations in the contiguous United States. J. Wildl. Manag. 74 (7), 1421-1424.

Mech, L.D., 2012. Is science in danger of sanctifying the wolf? Biol. Conserv. 150, 143-149.

Melis, C., Jędrzejewska, B., Apollonio, M., Bartoń, K.A., Jędrzejewski, W., Linnell, J.D.C. Kojola, I., Kusak, J., Adamic, M., Ciuti, S., Delehan, I., Dykyy, I., Krapinec, K., Mattioli, L., Sagaydak, A., Samchuk, N., Schmidt, K., Shkvyrya, M., Sidorovich, V.E., Zawadzka, B., Zhyla, S., 2009. Predation has a greater impact in less productive environments: variation in roe deer, Capreolus capreolus, population density across Europe. Glob. Ecol. Biogeogr. 18 (6), 724-734.

Middleton, A.D., 2014. Is the wolf a real American hero? The New York Times March 9 2014. Available at: http://www.nytimes.com/2014/2003/2010/opinion/is-the-wolfa-real-american-hero.html?ref=opinion\&_r $=2010$.

Middleton, A.D., Kauffman, M.J., McWhirter, D.E., Jimenez, M.D., Cook, R.C., Cook, J.G., Albeke, S.E., Sawyer, H., White, P.J., 2013a. Linking anti-predator behaviour to prey demography reveals limited risk effects of an actively hunting large carnivore. Ecol. Lett. 16 (8), 1023-1030.

Middleton, A.D., Morrison, T.A., Fortin, J.K., Robbins, C.T., Proffitt, K.M., White, P.J. McWhirter, D.E., Koel, T.M., Brimeyer, D.G., Fairbanks, W.S., Kauffman, M.J., 2013b. Grizzly bear predation links the loss of native trout to the demography of migratory elk in Yellowstone. Proc. R. Soc. B 280 (1762), 1-8.

Mitchell, C.D., Chaney, R., Aho, K., Kie, J.G., Bowyer, R.T., 2015. Population density of Dall's sheep in Alaska: effects of predator harvest? Mammal Res. 60 (1), 21-28.

Molles, M., 2012. Ecology: Concepts and Applications. sixth ed. McGraw-Hill Science/Engineering/Math, New York.

Morgan, H.R., Hunter, J.T., Ballard, G., Reid, N.C.H., Fleming, P.J.S., 2017. Trophic cascades and dingoes in Australia: does the Yellowstone wolf-elk-willow model apply? Food Webs 12, 75-86.

Moseby, K.E., Read, J.L., Paton, D.C., Copley, P., Hill, B.M., Crisp, H.A., 2011. Predation determines the outcome of 10 reintroduction attempts in arid South Australia. Biol. Conserv. 144 (12), 2863-2872.

Muhly, T.B., Hebblewhite, M., Paton, D., Pitt, J.A., Boyce, M.S., Musiani, M., 2013. Humans strengthen bottom-up effects and weaken trophic cascades in a terrestrial food web. PLoS One 8 (5), e64311.

Newsome, A.E., Catling, P.C., Cooke, B.D., Smyth, R., 2001. Two ecological universes separated by the dingo barrier fence in semi-arid Australia: interactions between landscapes, herbivory and carnivory, with and without dingoes. Rangel. J. 23 (1), 71-98.

Newsome, T.M., Ballard, G., Crowther, M.S., Dellinger, J.A., Fleming, P.J.S., Glen, A.S. Greenville, A.C., Johnson, C.N., Letnic, M., Moseby, K.E., Nimmo, D.G., Nelson, M.P., Read, J.L., Ripple, W.J., Ritchie, E.G., Shores, C.R., Wallach, A.D., Wirsing, A.J., Dickman, C.R., 2015. Resolving the value of the dingo in ecological restoration. Restor. Ecol. 23 (3), 201-208.

Nimmo, D.G., Watson, S.J., Forsyth, D.M., Bradshaw, C.J.A., 2015. Dingoes can help conserve wildlife and our methods can tell. J. Appl. Ecol. 52 (2), 281-285.

Olson, E.R., Stenglein, J.L., Shelley, V., Rissman, A.R., Browne-Nuñez, C., Voyles, Z., Wydeven, A.P., Van Deelen, T., 2015. Pendulum swings in wolf management led to conflict, illegal kills, and a legislated wolf hunt. Conserv. Lett. 8 (5), 351-360.

Orians, G.H., Cochran, P.A., Duffield, J.W., Fuller, T.K., Gutierrez, R.J., Haneman, W.M., James, F.C., Kareiva, P., Kellert, S.R., Klein, D., McLellan, B.N., Olson, P.D., Yaska, G., 1997. Wolves, Bears, and Their Prey in Alaska: Biological and Social Challenges in Wildlife Management. National Research Council, Washington DC.

Paine, R.T., 1980. Food webs: linkage, interaction strength and community infrastructure. J. Anim. Ecol. 49 (3), 666-685.

Painter, L.E., Beschta, R.L., Larsen, E.J., Ripple, W.J., 2015. Recovering aspen follow changing elk dynamics in Yellowstone: evidence of a trophic cascade? Ecology 96 (1), 252-263.

Palomares, F., Gaona, P., Ferreras, P., Delibes, M., 1995. Positive effects on game species of top predators by controlling smaller predator populations: an example with lynx, mongooses, and rabbits. Conserv. Biol. 9 (2), 295-305.

Palomares, F., Ferreras, P., Travaini, A., Delibes, M., 1998. Co-existence between Iberian lynx and Egyptian mongooses: estimating interaction strength by structural equation modelling and testing by an observational study. J. Anim. Ecol. 67 (6), 967-978.

Parsons, E.W.R., Maron, J.L., Martin, T.E., 2012. Elk herbivory alters small mammal assemblages in high-elevation drainages. J. Anim. Ecol. 82, 459-467.

Pasanen-Mortensen, M., Elmhagen, B., 2015. Land cover effects on mesopredator abundance in the presence and absence of apex predators. Acta Oecol. 67, 40-48.

Pasanen-Mortensen, M., Pyykönen, M., Elmhagen, B., 2013. Where lynx prevail, foxes will fail - limitation of a mesopredator in Eurasia. Glob. Ecol. Biogeogr. 22 (7), 868-877.

Peterson, R.O., Vucetich, J.A., Bump, J.M., Smith, D.W., 2014. Trophic cascades in a multicausal world: Isle Royale and Yellowstone. Annu. Rev. Ecol. Evol. Syst. 45, 325-345.

Platt, J.R., 1964. Strong inference: certain systematic methods of scientific thinking may produce much more rapid progress than others. Science 146 (3642), 347-353.

Prowse, T.A.A., Johnson, C.N., Cassey, P., Bradshaw, C.J.A., Brook, B.W., 2015. Ecological and economic benefits to cattle rangelands of restoring an apex predator. J. Appl. Ecol. 52, 455-466.

Pullin, A.S., Knight, T.M., 2009. Doing more good than harm: building an evidence-base for conservation and environmental management. Biol. Conserv. 142, 931-934.

Quinn, G.P., Keough, M.J., 2002. Experimental Design and Data Analysis for Biologists. Cambridge University Press, Cambridge. 
Ray, J.C., Redford, K.H., Steneck, R.S., Berger, J., 2005. Large Carnivores and the Conservation of Biodiversity. Island Press, Washington.

Reddiex, B., Forsyth, D.M., 2006. Control of pest mammals for biodiversity protection in Australia. II. Reliability of knowledge. Wildl. Res. 33 (8), 711-717.

Riginos, C., 2015. Climate and the landscape of fear in an African savanna. J. Anim. Ecol. 84 (1), 124-133.

Ripple, W.J., Beschta, R.L., 2003. Wolf reintroduction, predation risk, and cottonwood recovery in Yellowstone National Park. For. Ecol. Manag. 184 (1-3), 299-313.

Ripple, W.J., Beschta, R.L., 2004. Wolves and the ecology of fear: can predation risk structure ecosystems? Bioscience 54 (8), 755-766.

Ripple, W.J., Beschta, R.L., 2006. Linking wolves to willows via risk-sensitive foraging by ungulates in the northern Yellowstone ecosystem. For. Ecol. Manag. 230, 96-106.

Ripple, W.J., Beschta, R.L., 2007. Restoring Yellowstone's aspen with wolves. Biol. Conserv. 138 (3-4), 514-519.

Ripple, W.J., Wirsing, A.J., Beschta, R.L., Buskirk, S.W., 2011. Can restoring wolves aid in lynx recovery? Wildl. Soc. Bull. 35, 414-518.

Ripple, W.J., Beschta, R.L., Fortin, J.K., Robbins, C.T., 2014a. Trophic cascades from wolves to grizzly bears in Yellowstone. J. Anim. Ecol. 83 (1), 223-233.

Ripple, W.J., Estes, J.A., Beschta, R.L., Wilmers, C.C., Ritchie, E.G., Hebblewhite, M., Berger, J., Elmhagen, B., Letnic, M., Nelson, M.P., Schmitz, O.J., Smith, D.W., Wallach, A.D. Wirsing, A.J., 2014b. Status and ecological effects of the world's largest carnivores. Science 343, 151-163.

Ripple, W.J., Beschta, R.L., Fortin, J.K., Robbins, C.T., 2015. Wolves trigger a trophic cascade to berries as alternative food for grizzly bears. J. Anim. Ecol. 84 (3), 652-654.

Ripple, W.J., Chapron, G., López-Bao, J.V., Durant, S.M., Macdonald, D.W., Lindsey, P.A. Bennett, E.L., Beschta, R.L., Bruskotter, J.T., Campos-Arceiz, A., Corlett, R.T., Darimont, C.T., Dickman, A.J., Dirzo, R., Dublin, H.T., Estes, J.A., Everatt, K.T., Galetti, M., Goswami, V.R., Hayward, M.W., Hedges, S., Hoffmann, M., Hunter, L.T.B., Kerley, G.I.H., Letnic, M., Levi, T., Maisels, F., Morrison, J.C., Nelson, M.P., Newsome, T.M., Painter, L., Pringle, R.M., Sandom, C.J., Terborgh, J., Treves, A., Van Valkenburgh, B. Vucetich, J.A., Wirsing, A.J., Wallach, A.D., Wolf, C., Woodroffe, R., Young, H., Zhang, L., 2016a. Saving the world's terrestrial megafauna. Bioscience 35, 514-518.

Ripple, W.J., Estes, J.A., Schmitz, O.J., Constant, V., Kaylor, M.J., Lenz, A., Motley, J.L., Self, K.E., Taylor, D.S., Wolf, C., 2016b. What is a trophic cascade? Trends Ecol. Evol. 31, 842-849.

Ritchie, E.G., Johnson, C.N., 2009. Predator interactions, mesopredator release and biodiversity conservation. Ecol. Lett. 12 (9), 982-998.

Ritchie, E.G., Elmhagen, B., Glen, A.S., Letnic, M., Ludwig, G., McDonald, R.A., 2012. Ecosystem restoration with teeth: what role for predators? Trends Ecol. Evol. 27 (5), 265-271.

Ritchie, E.G., Dickman, C.R., Letnic, M., Vanak, A.T., 2014. Dogs as Predators and Trophic Regulators. In: Gompper, M.E. (Ed.), Free-ranging Dogs and Wildlife Conservation. Oxford University press, New York, pp. 55-68.

Ritchie, E.G., Schultner, J., Nimmo, D.G., Fischer, J., Hanspach, J., Kuemmerle, T., Kehoe, L. Dorresteijn, I., 2016. Crying wolf: limitations of predator-prey studies need not preclude their salient messages. Proc. R. Soc. B Biol. Sci. 283, 1834.

Russell, J.C., Blackburn, T.M., 2017. The rise of invasive species denialism. Trends Ecol. Evol. 32, 3-6.

Saggiomo, L., Picone, F., Esattore, B., Sommese, A., 2017. An overview of understudied interaction types amongst large carnivores. Food Webs 12, 34-38.

Sarewitz, D., 2012. Beware the creeping cracks of bias. Nature 485, 149.

Schmitz, O.J., Hamback, P.A., Beckerman, A.P., 2000. Trophic cascades in terrestrial systems: a review of the effects of carnivore removals on plants. Am. Nat. 155 (2) 141-153.

Sergio, F., Caro, T., Brown, D., Clucas, B., Hunter, J., Ketchum, J., McHugh, K., Hiraldo, F., 2008. Top predators as conservation tools: ecological rationale, assumptions, and efficacy. Annu. Rev. Ecol. Evol. Syst. 39, 1-19.

Sinclair, A.R.E., Metzger, K.L., Fryxell, J.M., Packer, C., Byrom, A.E., Craft, M.E., Hampson, K, Lembo, T., Durant, S.M., Forrester, G.J., Bukombe, J., Mchetto, J., Dempewolf, J., Hilborn, R., Cleaveland, S., Nkwabi, A., Mosser, A., Mduma, S.A.R., 2013. Asynchronous food web pathways could buffer the response of Serengeti predators to El Niño Southern Oscillation. Ecol. Appl. 94 (5), 1123-1130.

Sivy, K.J., 2015. Direct and Indirect Effects of Wolves on Interior Alaska's Mesopredator Community. Masters thesis. University of Alaska.

Smith, D.W., Peterson, R.O., MacNulty, D.R., Kohl, M., 2016. The big scientific debate: trophic cascades. Yellowstone Sci. 24 (1), 70-71.

Soulé, M.E., Estes, J.A., Miller, B., Honnold, D.L., 2005. Strongly interacting species: conservation policy, management, and ethics. Bioscience 55 (2), 168-176.

Squires, J.R., DeCesare, N.J., Hebblewhite, M., Berger, J., 2012. Missing lynx and trophic cascades in food webs: a reply to Ripple et al. Wildl. Soc. Bull. 36 (3), 567-571.

Sunde, P., Overskaug, K., Kvam, T., 1999. Intraguild predation of lynxes on foxes: evidence of interference competition? Ecography 22, 521-523.
Sustainable Human, 2014. 'How wolves change rivers.' (sustainable human, narrated by George Monbiot: accessed 6 July 2015). Available at: https://www.youtube.com/ user/TheSustainableMan.

Sutherland, W.J., Spiegelhalter, D., Burgman, M.A., 2013. Twenty tips for interpreting scientific claims. Nature 503, 335-337.

Terborgh, J., Estes, J.A., 2010. Trophic Cascades: Predator, Prey, and the Changing Dynamics of Nature. Washington D.C, Island Press.

Tercek, M.T., Stottlemyer, R., Renkin, R., 2010. Bottom-up factors influencing riparian willow recovery in Yellowstone National Park. West. North Am. Natural. 70 (3), 387-399.

Tiver, F., Andrew, M.H., 1997. Relative effects of herbivory by sheep, rabbits, goats and kangaroos on recruitment and regeneration of shrubs and trees in eastern South Australia. J. Appl. Ecol. 34, 903-914.

Treves, A., Krofel, M., McManus, J., 2016. Predator control should not be a shot in the dark. Front. Ecol. Environ.

Trouwborst, A., 2010. Managing the carnivore comeback: international and EU species protection law and the return of lynx, wolf and bear to western Europe. J. Environ. Law 22 (3), 347-372.

Trouwborst, A., 2015. Global large carnivore conservation and international law. Biodivers. Conserv. 24, 1567.

Underwood, A.J., 1997. Experiments in Ecology. Cambridge University Press, Cambridge.

Van Ballenberghe, V., 2006. Predator control, politics, and wildlife conservation in Alaska. Alces 42, 1-11.

Vucetich, J.A., Peterson, R.O., 2004. The influence of top-down, bottom-up and abiotic factors on the moose (Alces alces) population of Isle Royale. Proc. R. Soc. B Biol. Sci. 271 (1535), 183-189.

Vucetich, J.A., Smith, D.W., Stahler, D.R., 2005. Influence of harvest, climate and wolf predation on Yellowstone elk, 1961-2004. Oikos 111, 259-270.

Wallach, A.D., O'Neill, A.J., 2009. Threatened species indicate hot-spots of top-down regulation. Anim. Biodivers. Conserv. 32 (2), 127-133.

Wallach, A.D., Ritchie, E.G., Read, J., O'Neill, A.J., 2009. More than mere numbers: the impact of lethal control on the stability of a top-order predator. PLoS One 4 (9), e6861.

Wallach, A.D., Johnson, C.N., Ritchie, E.G., O'Neill, A.J., 2010. Predator control promotes invasive dominated ecological states. Ecol. Lett. 13, 1008-1018.

White, T.C.R., 2013. Experimental and observational evidence reveals that predators in natural environments do not regulate their prey: they are passengers, not drivers. Acta Oecol. 53, 73-87.

Wicks, S., Allen, B.L., 2012. Returns on Investment in Wild dog Management: Beef Production in the South Australian Arid Lands. Australian Bureau of Agricultural and Resource Economics and Sciences, Department of Agriculture, Fisheries and Forestry Canberra.

Wikenros, C., Ståhlberg, S., Sand, H., 2014. Feeding under high risk of intraguild predation: vigilance patterns of two medium-sized generalist predators. J. Mammal. 95 (4), 862-870.

Wikenros, C., Sand, H., Bergstrom, R., Liberg, O., Chapron, G., 2015. Response of moose hunters to predation following wolf return in Sweden. PLoS One 10 (4), e0119957.

Williams, B.K., Brown, E.D., 2014. Adaptive management: from more talk to real action. Environ. Manag. 53, 465-479.

Williams, J.E., Price, R.J., 2010. Impacts of red meat production on biodiversity in Australia: a review and comparison with alternative protein production industries. Anim. Prod. Sci. 50 (8), 723-747.

Winnie, J.A., 2012. Predation risk, elk, and aspen: tests of a behaviorally mediated trophic cascade in the Greater Yellowstone Ecosystem. Ecology 93 (12), 2600-2614.

Winnie, J., 2014. Predation risk, elk, and aspen: reply. Ecology 95 (9), 2671-2674.

Winnie, J., Creel, S., 2017. The many effects of carnivores on their prey and their implications for trophic cascades, and ecosystem structure and function. Food Webs 12, 87-93.

Wirsing, A.J., Buskirk, S.W., Ripple, W.J., Beschta, R.L., 2012. Wolves and lynx: plausible ideas make for testable hypotheses. Wildl. Soc. Bull. 36 (3), 572-577.

WMRC, 1996. Showdown in Alaska. Wolf Management Reform Coalition, Anchorage, Alaska.

Wolf, E.C., Cooper, D.J., Hobbs, N.T., 2007. Hydrologic regime and herbivory stabilize an alternative state in Yellowstone National Park. Ecol. Appl. 17, 1572-1587.

Zalasiewicz, J., Williams, M., Smith, A.M., Barry, T.L., Coe, A.L., Brown, P.R., Brenchley, P. Cantrill, D., Gale, A., Gibbard, P., Gregory, F.J., Hounslow, M.W., Kerr, A.C., Pearson, P., Knox, R., Powell, J., Waters, C., Marshall, J., Oates, M., Rawson, P., Stone, P., 2008. Are we now living in the Anthropocene? GSA Today 18 (2), 4-8.

Zar, J.H., 1999. Biostatistical Analysis. 4 ed. Prentice-Hall, New Jersey. 